\title{
DIREITO (ROMANO) E (BOA) RAZÃO: UMA ANÁLISE DO TRATAMENTO JURÍDICO DA ALFORRIA NO ENSAIO A ESCRAVIDÃO NO BRASIL DE PERDIGÃO MALHEIRO
}

Márlio Aguiar ${ }^{1}$

\section{Resumo}

O artigo tem por objetivo oferecer uma contribuição da história do direito para a história da escravidão brasileira no século XIX, com o intuito de demonstrar como o Direito era mobilizado para criar categorias e formas, operar institutos e dotar de linguagem jurídica fenômenos como a escravidão e a alforria. A pesquisa opera mediante análise do tratado jurídico A Escravidão no Brasil: Ensaio histórico, jurídico e social (1866) do Agostinho Perdigão Malheiro, em particular, do instituto técnico da manumissão ou alforria. Para tal, o artigo se divide em três partes: na primeira situação jurista e sua obra dentro do contexto intelectual e jurídico a respeito da escravidão na segunda metade do século XIX; na segunda, delineia a metodologia jurídica de Malheiro, percebendo-a ao mesmo tempo histórica e comparativa, e o modo como opera na tensão entre a aplicação de um direito histórico (o direito romano) e sua atualização pela "Boa Razão". Na terceira seção analisa-se como tal metodologia foi empregada efetivamente no tratamento da alforria, especialmente na discussão de sua natureza jurídica, de suas modalidades e no estatuto jurídico do statuliber. Malheiro, mostrar-se-á, opera através de um critério hermenêutico - a norma mais favorável à liberdade - para sua construção doutrinária.

Palavras-chave: Perdigão Malheiro; Manumissão; Alforria fideicomissária; Statuliber; Direito Romano subsidiário.

\footnotetext{
${ }^{1}$ Doutorando em Direito Civil (Direito Romano) pela Faculdade de Direito da Universidade de São Paulo (USP), Mestre em Teoria e História do Direito (UFSC), bacharel em Direito (UFSC) e História (UDESC). Membro do Grupo de Pesquisas em Latim e Fontes de Direito Romano: Ius Dicere(UFSC/CNPq).E-mail: marlio.aguiar@gmail.com
} 


\section{INTRODUÇÃO}

A historiografia a respeito da escravidão - seja nos meandros da história social, econômica, das ideias ou do direito - é vasta, refletindo a própria complexidade histórica de um fenômeno social e institucional que é uma marca de toda a história brasileira mesmo após a Lei Áurea. A relevância da escravidão para a própria constituição do Brasil explica a persistência da temática não obstante as contínuas variações metodológicas, teóricas e historiográficas a seu respeito ao longo das últimas décadas.

Este artigo tem por objetivo se inserir nas possíveis contribuições da história do direito à história da escravidão no Brasil da segunda metade do século XIX. Como parte da realidade institucional e dos discursos produzidos em sua época, a escravidão mobilizou não apenas o debate político e intelectual em geral, mas também o debate jurídico; igualmente, também as discussões a respeito do fim da escravidão e das possibilidades de sua abolição receberiam pelas lentes jurídicas e pela pena dos juristas um tratamento próprio, um delineamento específico, uma forma e linguagem jurídicas. O direito, tal qual um conhecimento que visa ao mesmo tempo dar a conhecer da realidade, mas também normatizá-la e regrá-la, não poderia deixar de se pronunciar a respeito da escravidão e de seus institutos correlatos, mesmo à revelia de grandes diplomas normativos.

Para tal, esta pesquisa centra suas atenções em um jurista, uma obra, uma metodologia jurídica e um instituto jurídico. O jurista é o mineiro Agostinho Perdigão Malheiro, formado em São Paulo, futuro deputado e plenamente inserido no debate geral e jurídico a respeito da escravidão. A principal obra a ser analisada, em três volumes, foi intitulada A Escravidão no Brasil: Ensaio histórico, jurídico e social (1866-1867), e dedica todo seu primeiro tomo ao direito aplicável à escravidão. A obra, verdadeira doutrina a respeito do direito concernente aos escravos, esboça um método histórico e comparativo: é através do direito romano, temperado pelo necessário olhar atualizante e pátrio, que Malheiro extrai a explicação dos institutos concernentes à escravidão. Desta feita, selecionamos para uma análise aquele ao qual o autor do Ensaio mais dedicou esforços: a manumissão ou alforria.

$\mathrm{O}$ artigo se divide em três partes. A primeira seção trata de apresentar sinteticamente a figura de Perdigão Malheiro na arena pública e no contexto do seu tempo: nesta etapa, damos destaque à sua produção bibliográfica, iniciada na segunda metade do século XIX, após sua formação jurídica em São Paulo e com sua entrada no Instituto Histórico e Geográfico Brasileiro e no Instituto dos Advogados Brasileiros. Tendo em vista o objetivo de perscrutar o pensamento jurídico e técnico do jurista a respeito da escravidão, esta seção tem por foco situá-lo no debate político, intelectual e jurídico do seu tempo a respeito da escravidão, da abolição e das formas de manumissão. Terminamos esta primeira seção dando destaque à obra que teremos em vista no restante deste artigo, o ensaio A Escravidão no Brasil.

$\mathrm{Na}$ segunda seção passamos à análise específica do primeiro volume da referida obra, dedicada ao direito vol.12, no. 01, Rio de Janeiro, 2019. pp.246-286 
relativo aos escravos e sua história, com o intento de perceber, no particular, como Perdigão Malheiro se serve do direito romano subsidiário como principal fonte do direito. Desta feita, iniciamos a seção discutindo o quadro normativo das fontes jurídicas do século XIX brasileiro (2.1) para, em seguida, analisar o modo como Malheiro utiliza simultaneamente do direito romano e das ideias de "boa razão", "espírito de época", "índole do povo" para extrair os principais institutos jurídicos relativos à escravidão (2.2) e seu principal guia hermenêutico, a norma mais favorável à liberdade.

$\mathrm{Na}$ terceira seção do artigo, à luz da metodologia histórico-jurídica do Ensaio, voltamo-nos para o tratamento técnico de um dos institutos jurídicos centrais daquela obra: a manumissão ou alforria. Nesse prisma, seguindo a argumentação de Malheiro, analisamos o modo como se faz valer tanto do direito romano subsidiário quanto de sua adaptação pátria (3.1) na distinção das formas de aquisição e manumissão, existentes no direito romano, abolidas no direito de seu tempo; (3.2) no conceito jurídico mesmo de manumissão, no momento em que busca definir sua natureza jurídica distinta de demais institutos como a doação (3.2.1) e, particularmente, na combinação com outros institutos jurídicos, mormente a liberdade fideicomissária, condicional e sob prazo (3.2.2) e, na esteira desta combinação, na conceituação jurídica dos statuliberi ou estados-livres (3.3).

\section{PERDIGÃO MALHEIRO, A ABOLIÇÃO MODERADA E O ENSAIO}

Agostinho Marques Perdigão Malheiro (紟1824, Vila de Campanha da Princesa, Minas Gerais; +1881, Rio de Janeiro $)^{2}$ foi um nítido representante do que era esperado, em termos biográficos ${ }^{3}$, de um notório homem público e de um intelectual brasileiro do século XIX. Jurista de formação, foi membro efetivo do IHGB, advogado

\footnotetext{
${ }^{2}$ Filho homônimo de Agostinho Marques Perdigão Malheiro (1788-1860) e D. Urbana Felisbina Candida dos Reis. Também jurista, o pai formara-se em Coimbra (1812), atuou como juiz de fora em diversas comarcas, provedor da Fazenda, foi desembargador na Relação da Bahia e do Rio de Janeiro, e, membro do Superior Tribunal de Justiça; também ele foi sócio do IHGB, além de Cavaleiro e Comendador da Ordem de Cristo e membro do Conselho do Imperador. Era por parte da mãe - filha de proprietários rurais - sobrinho do Marquês de Valença, Estèvão Ribeiro de Resende, também bacharel em direito formado nos quadros de Coimbra, o primeiro juiz de fora de São Paulo, desembargador na Relação da Bahia, desembargador do Paço, senador, conselheiro de Estado, Cavaleiro Fidalgo e sócio do IHGB.

${ }^{3}$ Perdigão Malheiro foi bacharel em Letras pelo Colégio Pedro II (1844) e concluiu seus estudos em Ciências Jurídicas e Sociais na Universidade de São Paulo (1848), à época vinculada à estrutura do Convento de São Francisco. Entrou no IHGB em 1850 e no IAB em 1851, sendo presidente dest'último (1861-1866). Ocupou os cargos de curador de africanos livres (1854), procurador de feitos da Fazenda (1855-1869) e advogado do Banco do Brasil (1876). Torna-se deputado pela província de Minas Gerais (18691872, 1875-1879) pelo Partido Conservador, retirando-se da vida pública por conta de um acidente vascular cerebral, vindo a falecer em 1881. Escapa aos limites deste artigo um desenvolvimento muito longo de sua trajetória bibliográfica e política, pela qual remetemos o leitor aos trabalhos de Spiller Pena (2001), Gileno (2003) e Santana (2014). A respeito da geração de estudantes de Direito da Faculdade de São Paulo daquele decênio, remeta-se ao clássico de VENÂNCIO FILHO, 2004, p. 136-160. Destaca o autor, por um lado, a marca de certo romantismo nacionalista (nas décadas de 40-50, formação de Perdigão Malheiro), idealismo e, especificamente no ensino jurídico da Faculdade de Direito, a ampla receptividade de autores da Escola Histórica alemã como Hugo e Savigny.
} 
e presidente honorário do IAB, deputado pelo Partido Conservador, procurador da Fazenda Nacional, curador de africanos livres e autor de obras a respeito da história do país e um analista da formação da Nação. Homem de época, o jurista mineiro deu atenção às questões concernentes à escravidão e à abolição tanto em suas obras escritas quanto em sua atuação pública. Embora não possamos fazer aqui uma longa digressão biográfica de Perdigão Malheiro, nem mesmo uma apreciação de toda a sua bibliografia, é preciso ter presente que este jurista está firmemente radicado num dado tempo e num dado espaço, seja no ambiente político do Império, seja no contexto intelectual-jurídico (que não se separam de modo absoluto em sua figura). Desta forma, um breve sumário a respeito do envolvimento público e intelectual de Perdigão Malheiro com a abolição será relevante para compreendermos em seguida, na seção subsequente, como é que o jurista enquadrava tecnicamente institutos correlacionados concernentes à escravidão.

Em julho do ano de 1850 Perdigão Malheiro publica pela Typographia Nacional do Rio de Janeiro seu Indice chronologico dos factos mais notáveis da historia do Brasil desde seu descobrimento em 1500 até 1849: seguido de um succinto esboço do estado do Paiz ao findar o anno de 1849, estudo de referência para seu próprio ingresso ao Instituto Histórico e Geográfico Brasileiro (IHGB). Embora o próprio autor saliente não se tratar de uma "História Geral do Brasil" - como fizera Varnhagen -, acompanhando "a marcha sucessiva dos acontecimentos notáveis de nossa Historia Contemporanea (...) em mui succinta exposição"4.

Nesta época, como outros políticos e homens públicos, Perdigão Malheiro centraliza sua atenção para os cotejos diplomáticos entre o Império do Brasil e a Inglaterra. E as razões para as contravenções do governo britânico - sua interferência nos mares e portos brasileiros -, destaca o jurista, não eram outras que não a continuação do tráfico de escravos, no contexto da Lei Palmerston (1839) e a Lei ou Bill Aberdeen (1845), que reverberariam nas discussões a respeito do direito internacional, bem como da soberania da Coroa e do Parlamento brasileiro5. Muito embora o Indice se dedique ao levantamento cronológico dos eventos da história interna e externa brasileiras - nest'última, em particular, os tratados internacionais firmados com a Inglaterra -, como anuncia no subtítulo da obra, Malheiro se posiciona em seu "succinto esboço do estado do Brasil ao findar do anno de 1849". O instituto mesmo da escravidão, pontuou na ocasião, manchava a história do país por pelo menos dois motivos. Como reflexo, a escravidão era nefasta à "educação de um povo", barbarizando aqueles que,

\footnotetext{
${ }^{4}$ MALHEIRO, Indice, 1850, p. 5.

${ }^{5}$ NABUCO, O Abolicionismo, 1883, p. 91, definiu o Bill Aberdeen como "uma affronta ao encontro da qual a escravidão forçou o governo Brazileiro a ir (...) Como se disse por diversas vezes no Parlamento Inglez, a Inglaterra fez com uma nação fraca o que não faria contra uma nação forte". Para Nabuco, no entanto, as "increpações" de homens como Lord Palmerston nem por isso fundamentavam, "a pretexto da dignidade nacional offendida" a posição do Governo brasileiro e a recusa de uma "alliança digna e honesta" contra o Tráfico (Opus cit, p. 94); já em seu ensaio A Escravidão, Nabuco condenara a continuidade e o aumento do tráfico após as desavenças diplomáticas com a Inglaterra (NABUCO, A escravidão, 1870, p. 90-99). Ver o clássico de BETHELL, 2002, p. 275-303; e SILVA JÚNIOR, 2015, p. 170-195.
} 
quotidianamente, conviviam com uma instituição violenta e cruel há séculos. Igualmente, a escravidão era um problema em si mesma: ela adicionava outro elemento de discórdia a um país já marcado pela "diversidade de raças", importando um obstáculo à civilização e à promoção do trabalho livre imigrante ${ }^{6}$ - de fato, a abolição da escravatura e a "colonização" em larga escala são apresentados pelo próprio Perdigão Malheiro como as duas primeiras necessidades do país?

Ao entrar no Instituto dos Advogados Brasileiros em 1851, Perdigão Malheiro se inseriu num debate já em andamento a respeito da escravidão, do mesmo modo que o IHGB já há algum tempo travava discussões a respeito da nacionalidade brasileira ${ }^{8}$. Como apontou Pena, entre as discussões "internas" do IAB na década de cinquenta estiveram duas em particular: a condição dos filhos nascidos de libertas sob condição (statuliber ou estado de liberdade, ao qual voltaremos infra) e os filhos nascidos entre escravas e seus senhores?

Caetano Alberto Soares já se pronunciara nas décadas anteriores a respeito da no texto Melhoramento da sorte nos escravos do Brasil (1847, fruto de um discurso de 1845), Sociedade contra o tráfico (1851) e Relatório da Exposição Nacional (1862), nestúltimo apontando, como também fizera Malheiro no Indice de

\footnotetext{
${ }^{6}$ MALHEIRO, Indice, 1850, p. 46; 51-52.

${ }^{7}$ MALHEIRO, Indice, 1850, p. 54.

${ }^{8}$ O IHGB foi fundado em 1838, poucos anos antes do IAB (1843). O IHGB protagoniza no Brasil, por longo tempo, a produção literária à respeito da história, contando com o apoio e o patrocinium do Imperador, tomando como uma das principais tarefas a de escrutinar o perfil da "nação" brasileira. O recrutamento do IHGB se dava pela via das relações sociais e sociabilização de uma sociedade de corte, escapando às regras e injunções do mundo acadêmico universitário europeu. Ver o clássico de GUIMARÃES, 1988 , p. 5-27.

${ }^{9}$ PENNA, 2001, p. 32-59. Um dos sentidos da tese de Penna é a de vinculação das posições jurídicas emancipacionistas brandas e moderadas destes juristas com uma Razão de Estado, a produção da ideologia do Estado imperial, expresso na ligação de muitos membros do IAB com o Parlamento e também com o Conselho de Estado. No entanto, acreditamos que não pode ser feita de modo tão automática a relação entre a produção jurídica do IAB e a introdução do positivismo jurídico no país. A defesa por parte de muitos juristas da necessidade de uma codificação civil, pela via legislativa, não implica per si em uma arraigada defesa do positivismo jurídico; não há um nexo, aqui, necessário. Igualmente, despertam cuidados certas expressões como "labirintos jurídicos" ou "sutilezas jurídicas e políticas sobre o direito romano", que podem guiar, desavisadamente, a uma certa análise cínica, por parte do intérprete-historiador, daquilo que efetivamente era dito, debatido e produzido entre os juristas do século XIX. O direito é uma prática social contínua - mesmo que não homogênea - que ganha corpo na linguagem e num conjunto de discursos marcados por certas exigências mínimas de conformidade, uma atitude reflexiva e no reconhecimento, tal qual já mostrara Hart, de que tais exigências são justificadas (ou, diríamos nós, podem ser justificadas). É exatamente na dimensão da apressada qualificação de "sutileza", isto é, a partir da linguagem de conceitos, argumentos e topoi jurídicos que podemos reconstruir historicamente as práticas sociais concretas que envolvem o direito. Isto nos parece importante: se, por um lado, espera-se a linguagem técnica e sofisticada na pena de um estudioso como Teixeira de Freitas, por outro, também homens como Perdigão Malheiro optaram pela linguagem jurídica não apenas no ambiente dos pares ou do foro, mas mesmo em suas atuações públicas e em seus discursos mais gerais. A consequência é que devemos levar a sério (sem descartar, ao menos de antemão, como retórica vazia ou cínica) o modo pelo qual os juristas decidem exprimir suas ideias e construir seus argumentos, especialmente, como no caso dos advogados do $\mathrm{IAB}$, quando se propõem a esclarecer questões controversas a respeito do direito aplicável. Lembre-se, por fim, que mesmo enquanto direito subsidiário, como discutiremos infra, direito romano permanecia direito vigente, fosse no Brasil, fosse mesmo nos territórios da futura Alemanha unificada. No que toca ao direito da escravidão, muito parcamente legislado - e na época de $A$ Escravidão no Brasil de Malheiro, antes mesmo da Lei de 1871 -, a discussão a respeito das fontes romanas e suas possibilidades de aplicação ganhava ainda maior relevo do que em outras esferas do direito privado.
} 
1850, a escravidão como um entrave à formação de uma indústria ${ }^{10}$. Para Soares, como para Malheiro, a escravidão nada tem de natural ${ }^{11}$; para o primeiro, inclusive, existem circunstâncias históricas muito particulares que tornam "desculpável" a escravidão forçada, frente à necessidade, por exemplo, de um povo como o lusitano cultivar e explorar uma imensa terra se utilizando de tais braços livres, ao menos, enquanto "taes circunstamcias persistirem ${ }^{\prime 12}$. Ambos concordariam igualmente com a necessidade de uma abolição gradual da escravidão, apta a se adequar ao tempo da vinda de novos imigrantes e do trabalho livre pleno.

Durante o período que ocupou a presidência do IAB (1861-1866) Perdigão Malheiro veio a aprofundar seu posicionamento a respeito da escravidão, numa fusão bastante típica da época que somava a erudição de uma educação de elite ${ }^{13}$ à sua formação jurídica. Desta época há o discurso de 1863, Ilegitimidade da propriedade constituída como escravo. A natureza de tal propriedade. A justiça e a conveniência da abolição da escravidão; $\mathrm{e}$ em que termos e, entre os anos de 1866-1867, a publicação dos três tomos da obra a qual dedicaremos maiores atenções, A Escravidão no Brasil: Ensaio historico-juridico-social (doravante, referenciada simplesmente como Ensaio, seguido do tomo respectivo).

O opúsculo de 1863, circulando na forma escrita pouco depois de ser proferido, é um dos reflexos das discussões, na Corte carioca, a respeito da escravidão no contexto da Guerra Civil americana e da Questão Christie, no acirramento da pressão diplomática oficial britânica em relação ao fim do tráfico brasileiro. Tal qual o haitianismo no começo do século (ainda presente na memória dos proprietários escravagistas), os acontecimentos, a proximidade da abolição da escravidão no sul dos Estados Unidos carregava consigo muito significado para os proprietários de escravos do maior Império do sul do continente. Tal período marca um momento significativo tanto na história institucional e diplomática do país quanto ao tráfico de escravos quanto, no que toca à trajetória do jurista em tela, momento em que era aguardado o posicionamento a respeito das "reformas sociais" necessárias pela voz do presidente do Instituto - o tema era assiduamente discutido no

\footnotetext{
${ }^{10}$ PENNA, 2001, p. 273-295; SANTANA, 2014, p. 38-39, 43-45, que estuda em pormenor a "linha antiescravista" presente no interior do IAB a partir da década de quarenta, com Caetano Alberto Soares, e numa segunda geração ou fase com Perdigão Malheiro na década de sessenta.

11 "No tempo de Saturno não havia escravo, nem senhor". Cf. SOARES, Memoria, 1847, p. 15.

${ }^{12}$ SOARES, Memoria, 1847, p. 14-15.

${ }^{13}$ Perdigão Malheiro estudara latim - seu manejo do Digesto é bastante evidente no tomo jurídico do ensaio $A$ Escravidão no Brasil, resultado também, certamente, dos estudos em direito romano no curso jurídico de São Paulo- e se movimentava com desenvoltura pela bibliografia francesa, anglófona e alemã. Nota-se que estava afinado com a bibliografia recente, inclusive o Histoire de l'esclavage dans l'Antiquité de Henri Wallon (1847). No particular jurídico, além da tratadística de Direito Privado lusitana e brasileira, demonstra íntimo contato com as obras de Leibniz, Pothier, Ortolan e, especialmente, "o profundo e analytico" Savigny. Um ponto a ser repensado, parece-nos, é em que extensão um autor como Malheiro se apropria e adapta pressupostos Savignianos do conceito de jurídico (particularmente, o método de "deputação" histórica das tradições jurídicas peculiares de um Povo). Certamente não estão todos: Perdigão não possui a mesma desconfiança antiliberal, anti-individualista e anti-legislativa presentes no Savigny do Beruf; por outro lado, é ao Savigny do Sistema (o "segundo Savigny", diriam comentadores como Grossi ou, sem usar a expressão, Wieacker) que ele mais se apega.
} 
ambiente público e na imprensa que circulava no Rio de Janeiro, e o discurso sobre a Ilegitimidade da escravidão ressoaria nas páginas dos jornais ${ }^{14}$.

Adiantando teses que pontilhariam veementemente o Ensaio, já em 1863 Perdigão Malheiro aponta uma crítica à visão de que o direito natural poderia ser fonte jurídica da escravidão. É inegável que a escravidão existia, de fato, como um instituto desde os tempos antigos: o sentido de sua fala é demonstrar, no entanto, que ela era simultaneamente (i) juridicamente infundada, posto que, mesmo mantida pela legislação positiva, violava o direito natural (que significa, também, os princípios de uma nação cristã); (ii) era, social e economicamente, nociva aos interesses da Nação. O diagnóstico a respeito da natureza jurídica última da escravidão já também estava presente neste breve opúsculo: a escravidão é uma propriedade ficta, contra à realidade das coisas; não se pode, verdadeiramente, tomar outros homens por propriedade. É este tipo de ficção - qualificada por ele repetidamente como odiosa e vil - que as leis civis regulam e, por esta mesma razão, se são somente as leis civis a sustentá-la, tanto maiores as razões para conduzir à sua abolição.

Embora fuja aos limites deste ensaio, é necessário que se faça uma breve menção a um discurso posterior de Perdigão Malheiro, enquanto deputado, utilizado por seus adversários para demonstrar as "incoerências" naquilo que doutrinava juridicamente no Ensaio sobre a Escravidão (1866-67) e suas ressalvas à lei de 1871. Trata-se do Discurso proferido na sessão da câmara temporária de 12 de julho de 1871 sobre a proposta do governo para a reforma do estado servil, quando se posiciona contra dispositivos do projeto da lei do ventre livre proposto pelo governo. A proposta governamental, ao contrário daquela que ainda tramitava no legislativo, não oferecia "a segurança necessária á propriedade, nem tão pouco o mais conveniente a bem do que fim que se tem em vista"15; a situação econômica do país e da agricultura não suportariam, em seu entender, a proposta tal qual se formulara ${ }^{16}$. É assim que Malheiros se coloca: não obstante a escravidão ser um mal absoluto a ser expurgado, a emancipação direta e igualmente absoluta é "um absurdo"17. A solução, destacou, seria uma emancipação

\footnotetext{
${ }^{14}$ SANTANA, 2014, p. 43-50, 6468.

${ }^{15}$ MALHEIROS, Discurso de 1871, p. 10.

${ }^{16}$ Veja v.g. MALHEIROS, Discurso de 1871, p. 12-13: “Senhores, eu não fallo assim porque seja escravagista, não; nesta questão faço grande violência ao meu coração; mas devo fazê-lo, porque quero que prevaleça a razão. (Apoiados.) Não se trata de uma discussão philosophica, não se trata de divagar no campo do abstracto e da metaphysica, não se trata de discorrer sobre principios religiosos, sobre principios philosophicos, do direito natural, da philosophia do direito, etc; não se trata de cousa alguma destas; trata-se do seguinte: admittida a justiça, conveniência e necessidade da extincção da escravidão, quaes os meios para se conseguir este fim, do modo o menos inconveniente que ser possa? Eis a única questão; mas questão difficilima”. Aqui o próprio Perdigão Malheiros mostra consciência não apenas da diferença de auditórios, mas do próprio âmbito de discurso. Não se trata de avençar ou discutir a hipótese teórica e técnico-jurídica de que uma lei institua a emancipação em determinados casos (algo que, aliás, Malheiros o fizera no primeiro tomo do Ensaio): trata-se de discutir a conveniência ou inconveniência política que tal possibilidade jurídica, já anteriormente afirmada, poderia ter. Explicita-o mais adiante: "A materia é assaz grave; não devemos proceder nesta reforma levianamente; eu já o disse aqui há dias. Não devemos fazer experiências sobre a nação, não direi como in anima vili, mas sim como in corpore vili" (Opus cit, p. 29).
}

${ }^{17}$ MALHEIROS, Discurso de 1871, p. 38-42. 
sucessiva ou gradual. Um pequeno trecho, já ao final do discurso, torna bastante eloquente e clara a posição abolicionista em tons moderados e brandos de Malheiro:

Senhores, as libertações vão-se succedendo como os pequenos rios a formarem um grande rio; por actos entre vivos e de ultima vontade, com cláusula ou sem ella, gratuitamente ou a titulo oneroso, de todas as idades, sexo e condição, e até a geração futura das escravas. Concorrem de modo notável em subscripções para tão caritativo e nobre fim. Liberta-se até ultimamente em massa, aos 20, 30, 40 e 100, por acto de ultima vontade sobretudo! E, não satisfeitos, dão-lhes educação, casão-nos e estabelecem-nos. Por fim deixão-lhes legados, ás vezes valiosos, e instituem seus herdeiros. De sorte que o progresso da libertação, da alforria, é exactamente um dos elementos mais poderosos com Entendo que não devemos fazer nesta questão, senão auxiliar o movimento espontâneo da emancipação; essas medidas de nascimento livre, resgate forçado absoluto, alforrias forçadas sem critério, e semelhantes, são perigosas, inconvenientes, vão fazer grande mal á idéa, grande mal ao paiz. que devemos contar; que não devemos desprezar, ao inverso animar ; e muito menos contrariar. Entendo que não devemos fazer nesta questão, senão auxiliar o movimento espontâneo da emancipação (apoiados); essas medidas de nascimento livre, resgate forçado absoluto, alforrias forçadas sem critério, e semelhantes, são perigosas, inconvenientes, vão fazer grande mal áidéa, grande mal ao paiz ${ }^{18}$.

Destaque-se, portanto, que não parece ser caso de, como afirmou Chalhoub, não haver nem mais "sombra daquele jurisconsulto aguerrido"19. Como demonstrou claramente Pena - que analisou, ademais, não apenas o Discurso de 1871, mas a carta que Malheiros escreveu no ano seguinte aos seus concidadãos de Minas Gerais, defendendo-se das acusações políticas de incoerência feitas à época -, as reflexões jurídicas das obras de 63 e 66-67 já estavam d'algum modo presentes ${ }^{20}$. Perdigão Malheiro não se tornara exatamente "mais conservador", como quis Chalhoub; ele era um conservador e um "inimigo da escravidão", e essas duas posições políticas foram efetivamente polos cambiantes e flutuantes de seu pensamento ${ }^{21}$, sendo que era o próprio Malheiro quem se qualificava como um moderado ${ }^{22}$. A posição efetiva de deputado da Nação - e, assim, o referido "recuo" em 1871 - o impelia a tomar decisões a respeito daquilo que escrevera; é nesse ponto que, concordamos com Pena, uma forma de "razão de Estado" é visível, sem importar em incoerência ou negação ${ }^{23}$; a questão ainda era, em 1871, como em 1867," de opportunidade e modo"24.

Antes de passar à próxima seção será útil apresentar a obra mais ambiciosa de Perdigão Malheiro, escrita

\footnotetext{
${ }^{18}$ MALHEIRO, Discurso de 1871, p. 44-45.

${ }^{19}$ CHALHOUB, 1990, p. 142.

${ }^{20}$ PENA, 2001, p. 52-54.

${ }^{21}$ Obras como o Ensaio são trabalhos diversos de um Discurso, afirmou o próprio Malheiros na ocasião: "não é de bom tom confundi-las [as obras] com os discursos, que mesmo tendo o seu valor, sofrem com o calor das discussões”. MALHEIROS, Discurso de 1871, p. 25.

${ }^{22}$ MALHEIRO, Ensaio, Tomo III, p. XI; e ainda, em outra ocasião, que "não sou o que algué pensa, um abolicionista a todo transe (...) eu sou abolicionista, mas moderado, nem posso deixar de ser considerado assim, sendo, como sou, conservador de coração e de cabeça”. MALHEIRO, Annaes do Parlamento brasileiro: Camara dos srs. Deputados, 1869, apud PENA, 2001, p. 324.

${ }^{23}$ Uma análise mais criteriosa a respeito da posição de Malheiros em 1871, com muitas outras nuances, é ofertada por SANTANA, 2014, p. 107-136; cf. SILVAJÚNIOR, 2015, p. 184186.

${ }^{24}$ MALHEIRO, Ensaio, Tomo III, p. XII.
} 
na segunda metade da década de sessenta e intitulada $A$ Escravidão no Brasil: Ensaio histórico-juridico-social (= Ensaio). Escrita pouco depois do opúsculo sobre a Ilegitimidade, é fruto do mesmo período em que Perdigão Malheiro ocupava a presidência do IAB e uma posição de destaque como jurista e intelectual especializado no tema.

A obra é dividida em três livros ou partes: a primeira delas, publicada em 1866, parte jurídica, tem por conteúdo o Direito Sobre os Escravos e Libertos, e será o cerne de nossas atenções; as outras duas, publicadas no ano seguinte, tratam respectivamente - segundo ele, nos prismas histórico, social, filosófico e econômico - dos Índios e dos Africanos, mais um Apêndice que reúne leis, alvarás, decretos, pareceres e projetos nacionais e estrangeiros que são citados ao longo da obra. $O$ primeiro livro possui, em verdade, um único título: $O$ escravo ante as leis positivas, E o liberto. Das cerca de duzentas páginas deste primeiro livro, quase metade delas são dedicadas à "Terminação do captiveiro" (Seção 3a) e às "Acções de liberdade e de escravidão" (Seção 4º). Embora examine rapidamente a situação dos escravos e dos libertos diante do direito penal, direito administrativo e dos direitos políticos, trata-se sobretudo de uma obra interessada nas relações civis, privadas, concernentes aos escravos e libertos, suas relações com os domini e com terceiros. Perdigão Malheiro se propõe a apresentar, de modo tão claro e metódico quanto possível, os princípios fundamentais e de maior frequência prática a respeito da escravidão, respondendo a "uma grande lacuna da nossa literatura jurídica".

Sua redação se iniciara em 1864 e se seguiria nos anos vindouros: como os demais em seu tempo, Malheiro assistiria assim ao fim da escravidão no sul dos Estados Unidos, à "vitória" brasileira na Guerra do Paraguai e ao episódio da carta da Junta de Emancipação Francesa entregue ao Imperador D. Pedro II, pontapé para as discussões legislativas a respeito do ventre livre e de outras modalidades de emancipação. O Ensaio se coloca no debate ao mesmo tempo como (i) um livro de análise da história da escravidão no país, seus institutos, usos e costumes e (ii) um conjunto de propostas críticas, à luz desta história, para o futuro desta nação escravista. Sendo assim, parece-nos que o Ensaio de Malheiro, como diagnóstico teórico de época, tal qual textos como O Abolicionismo de Nabuco duas décadas à frente, oferece não apenas uma reflexão sobre o tema proposto, a escravidão no Brasil, mas uma verdadeira leitura da escravidão como um elemento radical da história do até então Império; por mais que a trajetória intelectual da reflexão sobre a instituição geralmente comece com Casa Grande \& Senzala (1933) de Gilberto Freyre, há vigor histórico e sociológico na obra de Malheiro (ainda que datado, como qualquer documento, às circunstâncias de sua produção, público e época).

O historicismo comparatista é uma marca de todo o Ensaio. Por um lado, fa-lo Malheiros do mesmo modo que os autores franceses ou ingleses já o fizeram, por ele reiteradamente referenciados, cônscio, tal qual um 
Constant, que tanto na liberdade quanto na escravidão muito separa "os antigos" dos "modernos"25; que, em suma, seria ingênuo acreditar que a escravidão moderna se dera do mesmo moderno que a escravidão romana e que, do mesmo modo, o direito de uma sociedade não pode ser simplesmente transplantado através do espaço e do tempo. No que toca ao direito, em particular, essa análise, ao mesmo tempo histórica e comparativa, em nada deve ao método propugnado por alguns dos expoentes da Escola Histórica Alemã, como Gustav Hugo e o próprio Savigny ${ }^{26}$. Não se trata de uma historia magistra vitae, posto que cabe ao intérprete - a ele, o jurista e o historiador, ao menos na posição em que se encontra quando escreve o Ensaio - uma posição crítica e ativa, atenta ao "espírito do século"; igualmente, não se trata tampouco, como no Indice de 1850, de uma compilação mais comezinha de datas e eventos concernentes à história da escravidão, mas de identificar como a escravidão pôde surgir (seja no mundo antigo, especialmente o romano, seja no mundo moderno do Império colonial português), quais foram as suas principais consequências jurídicas ao longo deste iter e, em especial, por quais modos podia ser extinta. É assim que o próprio Malheiro apresenta, desta vez na introdução do terceiro e último tomo, um trabalho sobre a escravidão e a emancipação que não é apenas do passado, mas "(...) de presente, e sobretudo de futuro; porque refere-se à escravidão manutenida e existente, assim como á magna questão da abolição, e ao melhoramento da sorte dos escravos no Brasil"²7.

A segunda metade do século XIX é um período pungente para os temas da escravidão e da abolição, no que toca tanto à história institucional quanto à história das ideias, e Malheiro está inserido nessa enorme discussão que envolvia os grupos políticos dirigentes de seu tempo, bem como os proprietários de escravos e os próprios juristas. Da amplitude deste debate e dentro da obra jurídica de Perdigão Malheiro tencionamos, a partir das próximas seções deste artigo, perceber o tratamento jurídico que, a partir do Direito Romano (como direito subsidiário) e sujeito à manufatura intelectual do jurista, a escravidão recebeu no Ensaio sobre $A$ Escravidão no Brasil. Na seção seguinte enfocaremos o lugar do direito romano no panorama de fontes do direito de sua época e, num segundo momento, como o próprio Malheiro explicita seu método de análise e trabalho no primeiro tomo do Ensaio. Na terceira seção do artigo, levantados os esquadros metodológico-teóricos através dos quais o direito romano se torna matéria-prima "viva", mutável e sujeita à depuração pela "razão", analisaremos em pormenor a aplicação desta grelha teórica do tratamento privatista da alforria ou manumissão em Perdigão Malheiro.

\footnotetext{
${ }^{25}$ SANTANA, 2014, p. 72-83, 98-106, traz um comentário mais específico aos três tomos do Ensaio como um todo, e, no particular, ao modo como Malheiro mobiliza o argumento historicista. O peso da historicidade é muito claro no tomo primeiro: a nosso ver, no entanto, isto possivelmente indica não apenas o peso geral do "argumento histórico/nacional" (típico do período e, ademais, dos escritos de membros do IHGB), mas da própria metodologia de extrair o direito da história propícia ao pluralismo jurídico ainda vigente, especialmente em matéria tão sensível quanto pouco legislada. O quanto há de peso do método de busca do Volksgeist - o termo "influência" não parece nos ajudar aqui; limitamo-nos a notar as semelhanças - ainda é uma questão a ser pesquisada, mas que mereceria maiores atenções, ao menos quanto ao tratado jurídico que inicia o Ensaio.

${ }^{26}$ WIEACKER, 2010, p. 430-474.
} 


\section{DIREITO ROMANO SUBSIDIÁRIO E ESCRAVIDÃO BRASILEIRA}

Esta seção se compõe em duas etapas: discutimos, preliminarmente, o lugar ocupado pelo direito romano recepcionado como uma fonte subsidiária no ordenamento brasileiro do século XIX, especialmente no tema da escravidão (2.1); em seguida, o método histórico e comparativo explicitado pelo próprio Perdigão Malheiro para extrair a normatividade dos institutos da escravidão, depuração que passa pelo jurista, entre as "ficções" romanas do passado e à materialidade ou carnalidade dos institutos jurídicos do presente (2.2).

\section{O panorama normativo do Brasil Império e direito romano subsidiário em particular ao direito sobre a escravidão}

O jurista português Pascoal José de Melo Freire (1738-1798) cunhou em suas Instituições ao direito civil lusitano (1788) célebre frase - memorada por Nabuco e, antes dele, por Malheiro - quando se refere ao direito de escravidão: Servi, nigri in Brasilia, et quaesitis allis dominationibus tolerantur, sed quo jure et titulo me penitus ignorare fateor ${ }^{28}$. Deixemos de lado, por enquanto, a crítica ao próprio instituto da escravidão contida nesta oração e outras semelhantes que se seguirão; os juristas brasileiros, tal qual o jurista lusitano, estão cientes de que a escravidão existe ipso facto e que recebe - a despeito de ser injusta, cruel, contrária ao direito natural ou divino, infundada etc. - seu tratamento ou forma jurídicas, expresso em certo conjunto normativo, que nos cabe discutir, num pequeno cosmos de conceitos e categorias jurídicas, formando topoi de argumentos que é reconhecida por aqueles envolvidos na prática jurídica; em suma, uma tradução na linguagem do direito e dos juristas.

O Brasil Império do século XIX é, sob muitos aspectos da história institucional e do direito, o iter da formação de um Estado nacional moderno; no que tange à sua ordem jurídica, o Brasil da década de sessenta - a publicação do Ensaio ou A Escravidão no Brasil de Perdigão Malheiro ocorre nesta época - estava muito distante tanto da centralização política quanto da unificação normativa por meio da codificação. Um dos ideais tão arraigado em França - qual seja, a monopolização do poder de criação do direito, entendido como vontade do Estado, de modo a varrer o típico pluralismo jurídico e de fontes do direito que vigeu durante séculos na Europa

\footnotetext{
${ }^{27}$ MALHEIROS, Ensaio, Tomo III, p. VII.

28 "No Brasil, e noutros domínios dos descobrimentos, toleram-se os escravos negros; mas, confesso que ignoro com que direito a que título". MELO FREIRE, Institutiones Iuris Civilis Lusitani (Direito Civil Português), Livro 2 (Liber II - De Jure Personarum), Titulo 1 (De liberis et servis), \$12, 2a ed., 1828 [Trad. Instituições de Direito Civil Português, Livro II, p. 18]. Cita-o NABUCO, A Escravidão, 1870, p. 111; NABUCO, O Abolicinismo, 1883, p. 46 (oferecendo sua própria tradução: "Escravos negros são tolerados no Brasil e outros domínios; mas por que direito e com que título, confesso ignoral-o completamente"); igualmente, a mesma passagem é citada por MALHEIRO, Ensaio, Tomo I, p. 40, nota 164.
} 
do ius commune (entre o direito romano recepcionado e o direito canônico) dos iura propria, do direito feudal, etc. - , sobretudo com a difusão do modelo do Code Civil de 1804, respondia a uma temporalidade e a uma mentalidade que, se se espraiava por muitos países da Europa ${ }^{29}$, não se configurava plenamente em terras outras onde o Estado ainda não se encontrava plenamente unificado - como v.g. a Alemanha até a guerra francoprussiana - ou, em menor medida, ainda que existente, tendo por ausentes aqueles mesmos contornos institucionais propugnados pelo jusracionalismo e pelo Iluminismo que deram azo à Codificação, como no caso brasileiro.

Vigia no Brasil do século XIX, portanto, um persistente pluralismo no quadro das fontes do direito, usual tópico de introdução à reflexão a respeito do direito tanto na doutrina lusitana quanto na doutrina brasileira desde o século anterior. Por um lado, o Império possuía uma Constituição desde 1824; por outro, convivia com o mesmo panorama normativo que aos tempos da reforma pombalina se tencionara controlar e restringir por meio da Lei da Boa Razão (1769). Neste sentido, já apontando suas próprias convicções a respeito da quaestio da Codificação no ano de 1850, Perdigão Malheiro apontara no seu Indice a necessidade de que país confeccionasse um Código Civil "que substitua a tão emaranhada legislação que ainda nos rege"30, nos termos exigidos pelo art. 179, inciso XVIII da Constituição do Império ${ }^{31}$.

O jurista, quer aqueles da antiga metrópole, quer os do novo Império, tinha por entre as suas funções se mover por entre essa imensa - e certamente não unívoca - moldura, configurando verdadeiro campo de disputas a respeito do direito, ao mesmo tempo cognoscitivo (i.e., dizendo respeito à ciência do direito, ao saber específico dos juristas, e do modo como este enxerga e qualifica a realidade social por categorias próprias) e ordenador (uma vez que tal saber mobilizado e produzido pelos juristas não é puramente teorético: origina-se numa razão prática e dela se aplica na prática ou, pelo menos, fornece um painel axiológico que transparece nas razões de decidir

\footnotetext{
${ }^{29}$ Tem-se como exemplos o ALR da Prússia, o ABGB da Áustria, o código da Holanda (1838), bem como o Code Civil napoleônico que vigeu na Polônia e no reino Polaco, este substituído por código próprio em 1825. Cf. HESPANHA, 2010, p. 119; BUSTAMANTE, 2015 , p. 9497.

${ }^{30}$ MALHEIRO, Indice, 1850, p. 54. Também RIBAS, Curso, p. 299-311, dedica todo um capítulo a fornecer opinião "sobre a opportunidade das codificações", reportando-se desde à querela entre Savigny e Thibaut

em território tedesco, até a conveniência da codificação e unificação legislativa nos países que já tenham, simultaneamente, (i) elaborado sua nacionalidade - a grande construção intelectual e política do século XIX também no Brasil - e (ii) constituído uma jurisprudência capaz de organizar o direito de tal sorte - uma vez que, de modo muito próximo ao Berufde Savigny, Ribas aponta que a organização do direito civil é antes um trabalho que exige conhecimento teórico e prático, a ser elaborado por profissionais e estudiosos, e não o burburinho e a agitação das assembleias políticas (no que parece ser a típica confiança, intelectualmente aristocrata, frente ao "arbitrário" direito legislado).

31 "Art. 179. A inviolabilidade dos Direitos Civis, e Politicos dos Cidadãos Brazileiros, que tem por base a liberdade, a segurança individual, e a propriedade, é garantida pela Constituição do Imperio, pela maneira seguinte (...) XVIII. Organizar-se-ha quanto antes um Codigo Civil, e Criminal, fundado nas solidas bases da Justiça, e Equidade."
} 
daqueles que detém autoridade para tal $)^{32}$. A título de exemplo, o quadro a seguir apresenta duas sistematizações (com suas respectivas categorizações) das fontes de direito privado ofertadas por juristas brasileiros, Lourenço de Trigo Loureiro (1793-1870) e Antônio Joaquim Ribas (1818-1890).

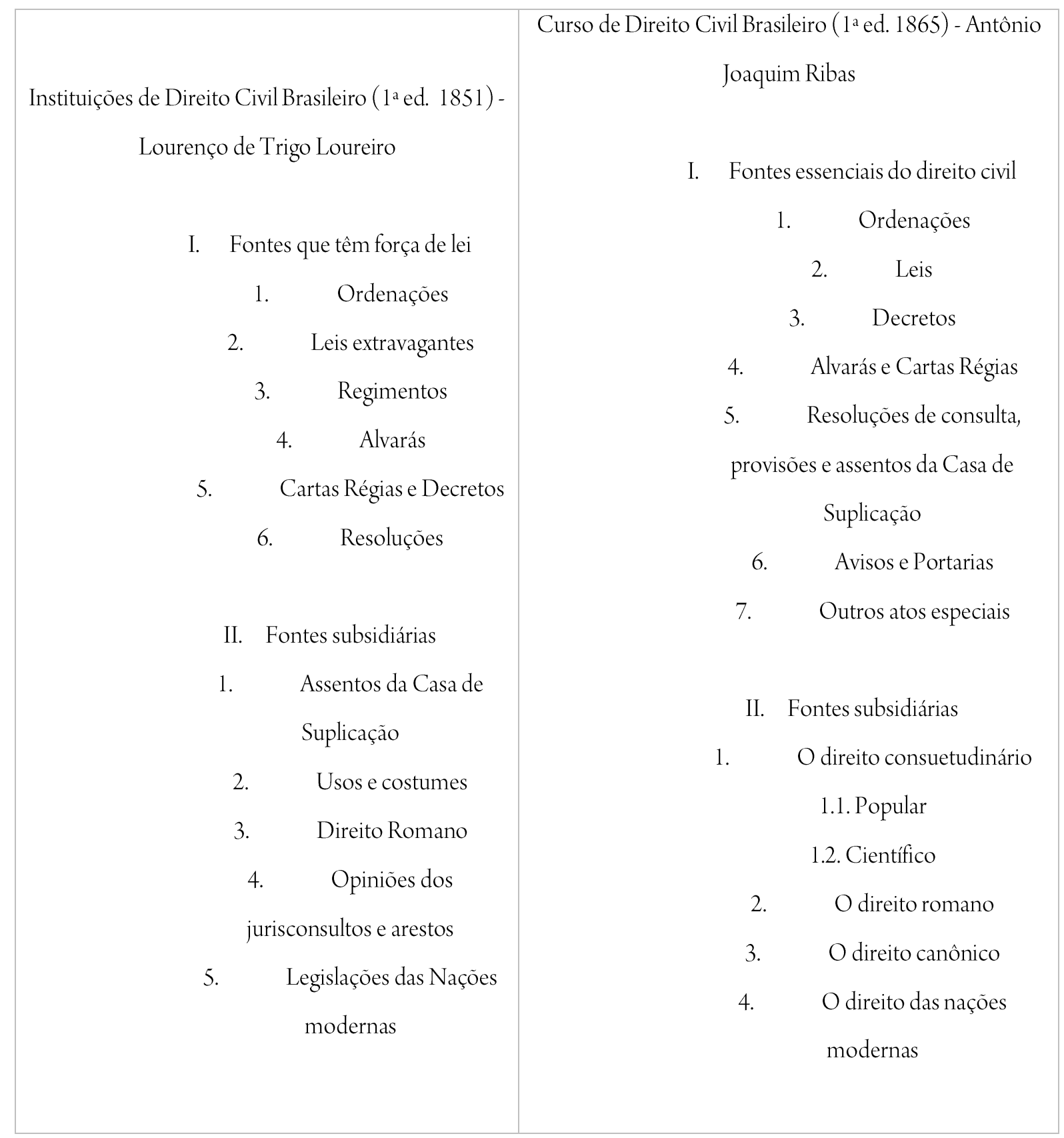

\footnotetext{
${ }^{32}$ I.e., no saber jurídico encontramos ao mesmo tempo o elemento de uma "descrição contemplativa" de uma parte da realidade político-social (como encontramos em outros saberes especializados) quanto os dispositivos que devem servir para facilitar o funcionamento efetivo da realidade social ou que, pelo menos, deveriam funcionar para tal; esses dois lados são dificilmente discerníveis ou separáveis entre si no que toca ao pensamento jurídico.
} 
Como buscou demonstrar Hespanha em artigo mais alongado a respeito das razóes de decidir na doutrina do século XIX, "o quadro efectivo das fontes do direito pode variar muito sensivelmente ainda quando os dados legislativos que lhe dizem respeito se mantêm inalterados" ${ }^{33}$ - fator este que não está ligado, portanto, à variação na atividade legislativa (que é a mesma), mas ora a fatores subjetivos e peculiares destes autores, ora a fatores objetivos das respectivas práticas discursivas-jurídicas (incluindo, portanto, as representações acerca do direito, sua adequação e sua compatibilidade com o contexto sociocultural em que aquele se aplica). As fontes tipicamente "modernas"34 - marcadas em sua gênese pelo convencionalismo, pelo individualismo e pelo jusnaturalismo, quer em ambientes liberais, quer em ambientes do Despotismo Ilustrado -, ainda que, em tese, superiores às fontes subsidiárias, convivem com seculares formas de direito romano, direito eclesiástico e direito costumeiro.

O quadro normativo, mesmo com variações, é unânime em situar o direito como como uma fonte subsidiária (ainda que, na realidade, o peso desta fonte "subsidiária" varie muito entre os civilistas). A Lei da Boa Razão (1769), ainda no período colonial, estabelecera um critério - bastante móvel, é verdade - para a aplicação de certos dispositivos de direito romano em detrimento de outros, a autoridade intrínseca da boa razão ${ }^{35}$, e vedara

A distinção, de tom weberiano, é empregada aqui do mesmo modo que a emprega o florentino Pietro Costa em sua obra a respeito da iurisdictio, v.g.cf.COSTA, 2002, p. xci-xcv.

${ }^{33}$ HESPANHA, 2010, p. 150. A análise do historiador do direito é mais ampla do que a nossa e leva em conta não apenas os brasileiros Trigo Loureiro e Joaquim Ribas, mas também o já citado Paschoal de Melo Freire e José Homem Correia Teles (17801849), com o cuidado não apenas de contextualizar tais manuais e seus autores na história portuguesa, mas a diversidade, dentro das próprias obras, do universo de referências normativas e mesmo, quantitativa e estatisticamente, do uso das fontes de direito privado. Daíse referir o autor a pelo menos dois grandes "eixos", dentro de uma teoria ou quadro das fontes do direito, pelos quais transitam tais civilistas: um eixo legalista-doutrinarista (mais largamente apoiado num direito doutrinal, forjado pelos juristas) e um eixo tradicionalista-modernista (mais intimamente jusracionalista e orientado pelo usus modernus alemão e pela praxística portuguesa).

${ }^{34}$ Cumpre enfatizar que embora tratemos de fontes relativamente antigas, como as Ordenações Filipinas -que não são em nada comparáveis aos modernos Códigos em sua configuração, sistematização e vulto, sendo antes, tal qual o antigo direito justinianeu, compilações-, é moderna a tentativa de sistematizar e hiarquizar as fontes do direito, tal qual pelo menos tencionara resolver a Lei da Boa Razão para os territórios de Portugal.

${ }^{35}$ Lei da Boa Razão, $\$ 90$. "Sendo-me presente, que a Ord. L. 3 Tit. 64 no Preâmbulo, que mandou julgar os casos omissos nas Leis Pátrias, estilos da Corte e costumes do Reino, pelas Leis, que chamou Imperiais, não obstante a restrição, e a limitação, finais do mesmo Preâmbulo contidas nas palavras $=$ As quais Leis Imperiais mandamos somente guardar pela boa razão, em que são fundadas =, se tem tomado por pretexto; tanto para que as Alegações, e Decisões se vão pondo em esquecimento as Leis Pátrias, fazendo-se uso somente das dos Romanos; como para se argumentar, e julgar pelas ditas Leis de Direito Civil geral, e indistintamente, sem se fazer diferença entre as que são fundadas naquela boa razão, que a sobredita ordenação do Reino determinou por único fundamento para as mandar seguir; e entre as que ou têm visível incompatibilidade com a boa razão, ou não tem razão alguma, que possa sustenta-las, ou têm por únicas razões, não só os interesses dos diferentes partidos, que nas revoluções da Republica, e do Império Romano, governaram o espírito dos seus Prudentes, e Consultos, segundo as diversas facções, e Seitas, que seguiram; mas também tiveram por fundamento outras razões assim de particulares costumes dos mesmos Romanos, que nada podem ter de comuns com os das Nações, que presentemente habitam a Europa, como superstições próprias de Gentilidade dos mesmos Romanos, e inteiramente alheias da Cristandade dos Séculos, que depois deles se seguiram: Mando por uma parte, que debaixo das penas ao diante declaradas se não possa fazer uso das ditas Alegações, e Decisões de Textos, ou de Autoridades de alguns Escritores, em quanto houver Ordenações do Reino, Leis Pátrias, e usos dos Meus Reinos legitimamente aprovados também na forma abaixo declarada: E Mando pela outra parte, que aquela boa razão, que o sobredito Preâmbulo determinou, que 
o recurso à Glosa de Acúrsio e aos Comentários de Bártolo. A boa razão se constituía assim, comentava Antônio Joaquim Ribas, nos "primitivos princípios que contém verdades essenciaes, intrínsecas, e inalteráveis, estabelecidos pela ethica, ou pelos direitos divino e natural; ou nas regras que de universal consentimento estabeleceu o direito das gentes; ou nas leis politicas, economicas, mercantis e marítimas das nações christãs ${ }^{\prime \prime 36}$. Para o legislador pombalino o direito romano deveria ser utilizado e interpretado naquilo que vá ao encontro do direito pátrio do reino; ao menos em tentativa, a Lei da Boa Razão buscara domar nas mãos da Coroa o pluralismo de fontes do direito e subordinar, aonde outras fontes fossem necessárias, a interpretação do direito romano à lógica da legislação rea ${ }^{37}$ da própria reforma pombalina do ensino jurídico universitário de acordo com os seus novos Estatutos.

A posição legalista tencionada pela Lei da Boa Razão encontra boa explicação e guarida em José Homem Corrêa Telles (1780-1849), que produziu um Comentário Crítico à Lei da Boa Razão (1824), referenciado por Perdigão Malheiro justamente a este propósito. Telles, ao comentar o já referido $\$ 9$ da Lei, considerou:

Depois da nossa Lei dizem os Estatutos da Univ. L. 2. Tit. 2. cap. 3. \$. 4: 'O Direito Romano apenas pôde obter força, e auctoridade de Lei em supplemento do Pátrio, onde se não estendem as rovidencias das Leis nacionaes, e quando é fundado na boa razão, que lhe serve de único fundamento. Assim foi mandado observar nestes Reinos desde a Legislação do Senhor D. João I. nos sobredictos casos, que haviam sido omitlidos nas Leis Pátrias, e a que não se estendia ou a identidade de razão, ou o espirito das mesmas Leis Pátrias. E neste mesmo verdadeiro sentido o tenho ordenado e estabelecido lambem da mesma sorte na Minha L. de 22 de Agosto de 1769, para reprimir os intoleráveis abusos, e excessos de auctoridade, que nestes Reinos se dava ás dietas Leis Romanas em prejuízo das Leis Pátrias: fixando os justos limites, e os certos casos, em que ellas podem ter ainda alguma auctoridade, e o uso legitimo, que nos dictos casos se pôde fazer ainda d'ellas nestes Reinos' (...) D'aqui se colhe que as Leis Romanas tem auctoridade extrinseca, nos casos omissos não só na lettra, mas também no espirito das Leis Pátrias, se acaso aqueilas forem fundadas na boa razão. Os casos omissos na leitura das Leis Pátrias, mas compreendidos no espirito d'ellas, por identidade de razão, e por força de comprehensão, devem julgar-se lambem pelas Pátrias, e não pelas Romanas, ainda que estas pareçam fundadas em boa razão. ${ }^{38}$

Outrossim, como destacou Barbosa, eventuais efeitos limitadores da Lei da Boa Razão conviviam, na verdade, com o recurso à literatura jusracionalista, com o usus modernus do direito romano (ainda que fundado

fosse na praxe de julgar subsidiaria, não possa nunca ser a da autoridade extrínseca destes, ou daqueles Textos do Direito Civil, ou Abstractos, ou ainda com a concordância de outros; mas sim, e somente: Ou aquela boa razão, que consiste nos primitivos princípios, que contém verdades essenciais, intrínsecas, e inalteráveis, que a Ética dos mesmos Romanos havia estabelecido, e que os Direitos Divino, e Natural, formalizaram para servirem as Regras Moraes, e Civis, entre o Cristianismo: Ou aquela boa razão, que se funda nas outras Regras, que de universal consentimento estabeleceu o Direito das Gentes para a direcção, e governo de todas as Nações civilizadas: Ou aquela boa razão, que se estabelece nas Leis Políticas, Económicas, Mercantis, e Marítimas, que as mesmas Nações Cristãs tem promulgado com manifestas utilidades, do socego público, do estabelecimento da reputação, e do aumento dos cabedais dos Povos, que com as disciplinas destas sábias, e proveitosas Leis vivem felizes à sombra dos tronos, e debaixo dos auspícios dos seus respectivos Monarcas, Príncipes Soberanos".

${ }^{36}$ RIBAS, Curso, p. 168.

${ }^{37}$ Lei da Boa Razão, $\$ 10^{\circ}$.

${ }^{38}$ CORREA TELLES, Comentario, p. 32; citado especificamente para este fim em MALHEIRO, Ensaio, Tomo I, p. 137, nota 642. 
no argumento da razão) e com a remissão ao direito estrangeiro, o que antes permitia o aumento da complexidade do direito privado pátrio ${ }^{39}$. A civilística brasileira aqui, não distante da lusitana, mesmo no contexto de formação de um Estado nacional monárquico, deve muito a esta valorização do direito doutrinal, da contribuição metodológica do usus modernus e, adiante, da Pandectística ${ }^{40}$ - tratava-se mais de uma "permanência, sob as contínuas alterações legislativas, de um núcleo de princípios permanentes"41 do que de uma ruptura por meio da Boa Razão; ou ainda, que as transformações que efetivamente se dão após a Boa Razão se deram não por força em si daquele ato legislativo, mas pelas condições em que foi recepcionada pela ciência jurídica e pelo ideário iluminista dos séculos XVIII e XIX em Portugal e Brasi ${ }^{42}$.

Não é de nossa alçada adentrar no debate a respeito da recepção e eventuais revezes da Lei da Boa Razão e das reformas pombalinas no século XVIII; interessa-nos, no entanto, apontar que (i) ao menos na forma como a civilística passa a explicar as "fontes do direito civil", passa-se a tomar o direito romano como subsidiário ao pátrio (ainda que isso não signifique, não necessariamente, um fortalecimento profundo da lei estatal-real em detrimento do declínio do antigo direito ensinado nas universidades ${ }^{43}$ e que (ii) mesmo quando aplicável, o direito romano era suscetível à boa razão. Jurista escrevendo um século à frente e noutro momento do contexto de formação do seu próprio Estado nacional, Malheiro partilhará dessas duas premissas para analisar o direito romano. Como escreveu Trigo Loureiro:

O Direito Romano constitue entre nós a mais copiosa fonte subsidiaria da nossa jurisprudência civil, já porque as Ordenações expressamente o mandão observar em muitos casos, já porque a citada Lei de 18 de Agosto de 1769 o declarou subsidiario do direito pátrio nos casos omissos nelle, ou incompletamente providenciados, uma vez que, na espécie sujeita, ele seja conforme á boa razão, ou direito natural, e não se basêe em motivos supersticiosos, e peculiares ao povo romano, ou em costumes, máximas, ou princípios regeitados pela civilisação moderna ${ }^{44}$.

\footnotetext{
${ }^{39}$ BARBOSA, 2009, p. 362-365.

${ }^{40}$ HESPANHA, 2009, p. 180-191. Como bem destaca Hespanha, esta é uma marca, inclusive, presente na obra de um jurista tal qual Teixeira de Freitas, encarregado do projeto de Código Civil pelo próprio imperador. Não é ao argumento político - "praxista", destaca o historiador português - ou pragmático que ele se volta na Introdução de sua obra, mas no argumento do sistema do direito; tal qual o projeto de um Melo Freire, a questão é reconstituir (mais até do que identificar) o tipo de "razão" imanente ao direito, seja na história (no recurso ao direito romano subsidiário, à história do direito, à metodologia do usus modernus), seja nas fontes normativas hodiernas.

${ }^{41}$ HESPANHA, 2009, p. 185.

${ }^{42}$ BUSTAMANTE, 2015, p. 101-109.

${ }^{43}$ Tampouco significaria o fim do recurso ao direito romano como parte do manancial formativo, argumentativo e de instrumental técnico dos juristas. Veja-se Joaquim Ribas: "O conhecimento profundo e completo do direito pátrio é impossível sem que se firme nas largas bases do direito romano; não só porque é este que se encontrão as razões históricas eficientes das legislações dos povos modernos, como porque elle é o mais bello, completo e majestoso monumento da sabedoria jurídica, que os passados séculos nos legárão", cf. RIBAS, Curso, 169.

${ }^{44}$ LOUREIRO, Instituições, Tomo I, p. 27. Diria também: “As leis pátrias devem, não só ser interpretadas, mas também executadas de conformida [sic] com o seu sentido litteral; isto é, de conformidade com a significação obvia e natural das palavras, sem as ampliações, que as respectivas matérias tiverem no Direito Romano, reprovada a falsa regra 'que as leis pátrias se devem restringir, quando são correctorias do direito romano, e devem receber todas as suas ampliações, e restricções, quando não são conformes"
} 
Estas considerações se fazem necessárias não apenas por, como colocou Hespanha, possivelmente indicarem uma subjacente "teoria das fontes do direito" na civilística - com sua intrínseca hierarquia entre fontes principais e subsidiárias, nest últimas, o direito romano - dos juristas do século XIX e, portanto, no paradigma intelectual do qual parte o ensaio jurídico sobre a escravidão de Perdigão Malheiro, mas para ressaltar que, no que tange ao tópico jurídico da escravidão há uma intensa discussão a respeito do uso e interação entre estas fontes; e, como veremos na subseção subsequente, que tal se torna particularmente evidente quando deitamos atenções ao tópico da escravidão - com seus institutos técnicos -, e às discussões inerentes ao uso e interpretação do direito romano e do direito moderno.

\section{Do Espírito de um Século e da Boa Razão: ficções romanas versus realidades pátrias em Perdigão Malheiro}

No que tocava à escravidão africana em terras brasileiras, era sobretudo o direito romano recepcionado, bem como os usos e costumes, que regiam as relações jurídicas privadas na ausência não apenas de uma Codificação civil quanto pelo nunca surgido "Código Negro" de que falara Augusto Teixeira de Freitas ${ }^{45}$. O direito romano - entendido aqui em referência ao Corpus Iuris Civilis ${ }^{46}$, especialmente ao Digesto e ao Codex; ladeado, eventualmente, da produção moderna a seu respeito, como o Sistema de Direito Romano Atual de Savigny e as Pandectas de Pothier -, fonte subsidiária do direito desde a Lei da Boa Razão, aparecia em primeiro plano para fornecer o principal bojo normativo do direito concernente aos escravos e à alforria. Outras fontes, evidentemente, também entravam no campo técnico e discursivo a respeito da escravidão ${ }^{47}$, como o Título XLIII do Livro $4^{\circ}$ das

(Opus cit p. 31); os melhores intérpretes da lei são a praxe, o estilo de julgar, os arestos, a prática [jurídica] geral (Opus cit.p. 3233).

${ }^{45}$ Cumpre advertir que não ha um só lugar do nosso texto, onde se trate de — escravos - Temos, é verdade, a escravidão entre nós; mas, se esse mal é uma excepção que lamentamos, e que já está condemnado a extinguir-se em uma época mais ou menos remota, façamos tambem uma excepção, um capítulo avulso, na reforma das nossas Leis Civis, não as maculemos com disposições vergonhosas, que não podem servir para a posteridade; fique o - estado de liberdade sem o seu correlativo odioso. As Leis concernentes à escravidão (que não são muitas) serão pois classificadas á parte, e formarão o nosso Codigo Negro". TEIXEIRA DE FREITAS, Consolidação, 1876, p. XXXVII. A partir da 2a edição da Consolidação, especialmente em seus comentários em rodapé ao art. 42 sobre divisão de bens ( $\mathrm{o} \mathrm{"Código} \mathrm{Negro} \mathrm{de} \mathrm{rodapé"} \mathrm{de} \mathrm{que} \mathrm{fala} \mathrm{Pena),} \mathrm{Teixeira} \mathrm{de} \mathrm{Freitas} \mathrm{procederia} \mathrm{uma} \mathrm{análise}$ da matéria sobre escravidão e manumissão. Quanto a Teixeira de Freitas no particular, ver PENA, 2001, p 71-128.

${ }^{46}$ RIBAS, Curso, p. 173: "É o direito romano, tal qual ficou formulado na compilação de Justiniano que entre nós é aceito como subsidiário do patrio"; e ainda, "Os textos das leis romanas não são entre nós subsidiariamente obrigatórios por si mesmos; é necessário que se revistão da fórma do direito consuetudinário nacional, ou estrangeiro" (Opus cit, p. 169).

${ }^{47}$ WEHLING, 2009, p. 390-392, que aponta, quanto às relações privadas: as Ordenações Filipinas, o Código Comercial de 1850, a legislação colonial não derrogada, leis civis ordinárias, atos administrativos do Império, a jurisprudência, os pareceres do IAB e, subsidiariamente, o direito romano e o direito canônico; quanto às relações criminais, o Código Criminal de 1830, o Código de Processo Criminal e a legislação ordinária. 
Ordenações Filipinas ${ }^{48}$, legislações extravagantes - como as legislações que viriam a regulamentar o ventre livre e o pecúlio - e as próprias práticas e decisões dos tribunais brasileiros. Um "velho" e experimentado direito romano, e um "novo" direito privado, encontram ambos não apenas assento nas obras jurídicas como, veremos em Perdigão Malheiro, oferecem uma excelente janela para o modo como os juristas se serviam desta argumentação e desta tensão (antigo/novo, inadequado/adequado, estrangeiro/nacional, ficção/realidade) em tema candente como a escravidão.

É neste sentido que se enquadram como significativas não apenas a frase de Melo Freire - que direito, afinal, se aplica à escravidão? -, mas também as ponderações dos brasileiros que pensaram a respeito do tema. Em seu texto A Escravidão (1870), Joaquim Nabuco apontara para esta ambivalência: ao mesmo tempo que o direito romano não é nosso direito, isto é, nem é direito pátrio, nem direito do tempo presente ${ }^{49}$, é através deste mesmo direito, com um consciente e atualizador uso da razão que se é possível extrair um direito relativo à escravidão ${ }^{50}$. Ao apresentar Ao Leitor sua própria obra, Malheiro destaca que a função do primeiro livro do ensaio Sobre a Escravidão visa fornecer o conhecimento a respeito do "Direito actual sobre os escravos". Poucas páginas à frente, no Prêambulo do mesmo tomo, Perdigão Malheiro pontua do que se trata, sobretudo, deste "direito atual":

Nossas leis são escassas e como que fugitivas a tal respeito [= o escravo e o liberto ante as leis positivas, matéria da primeira parte do Ensaio], principalmente nas infinitas relações cíveis que ligão os escravos e os senhores entre si e com terceiros, nas questões cardeais de estado de liberdade ou escravidão, e em tantas outras que emergem constantemente ${ }^{51}$.

Leis e normas modernas que dispõem sobre as relações civis que concernem aos escravos (com seus senhores e terceiros) são excepcionais no "Direito Civil Comum"52. O direito justinianeu emerge na pena de Malheiro, assim, como a fonte que mais desenvolveu o direito da escravidão, criou institutos, conceitos e uma

\footnotetext{
${ }^{48}$ Enquanto o título XLII trata das doações em geral, o título XLIII trata "das doações e alforria, que se podem revogar por causa da ingratidão"; chama a atenção, primeiro, que ao tempo das Ordenações a manumissão era considerada um tipo de doação (do que divergiram tanto Teixeira de Freitas quanto o próprio Perdigão Malheiro), e, em segundo lugar, a forte discussão de época entre os juristas a respeito da revogação deste título, ou de sua aplicação apenas entre os chamados libertos imperfeitos, por oposição àqueles "perfeitamente manumitidos", sem condição ou termo.

${ }^{49}$ NABUCO, 1870, p. 111: "As leis romanas sobre a escravidão não passaram de todo para o nosso direito e difíil é dizer em que devam ser aceitas, em que repudiadas. Esse estudo ainda não foi feito entre nós: não podemos fazê-los nos limites deste trabalho, no qual apenas mostraremos as dificuldades que um tal estudo comportaria (...) Não herdamos a escravidão dos romanos (...) estabeleceu-se no Brasil o cativeiro dos negros; era quase Portugal estranho a essa escravidão pessoal, alimentada pelo maior dos crimes; embora fosse ela a vida da colônia, foi deixada ao arbítrio dos interessados em mantê-la, dos senhores. A lei foi o costume. Não se pode assim atravessar tantos séculos para se ir buscar para os escravos a legislação romana. O estado da sociedade, das raças entre si, da civilização, as condições todas da existência da escravidão entre nós, são muito diferentes das condições da escravidão romana"; pelo que Nabuco aponta as dificuldades enfrentadas por Teixeira de Freitas nas sucessivas edições de suas Consolidaçōes das Leis Civis para "harmonizar as leis de uma sociedade com o estado de outra" (opus cit, p. 112).

${ }^{50}$ NABUCO, 1870, p. 112: "(...) a razão, acompanhada pela ciência dos costumes do país, é a única norma nos casos correntes. O direito romano, sujeito assim a uma crítica depuradora, invocamos nós também como a legislação para os escravos: por que estamos certos que nessa revisão dos preconceitos e dos erros antigos pelo espírito moderno de caridade e de justiça a razão terá a melhor parte e a equidade constituirá o fundo mesmo do direito".

${ }^{51}$ MALHEIRO, Ensaio, Tomo I, p. 1.

${ }^{52}$ MALHEIRO, Ensaio, Tomo I, p. 36.
} 
técnica jurídica aplicada a esse tipo de relação; direito subsidiário, é verdade, mas que por tal estado de coisas normativo ganha o centro das atenções em matéria de escravidão.

E, no entanto, esse mesmo direito romano - a "fonte mais abundante e rica de disposições a respeito" da escravidão" - "tantas vezes fluctuou contradictoria e incerta, rompendo quase sempre contra as regras geraes" 53 . Olhando para o devir histórico do direito do povo de Rômulo, especialmente na matéria da escravidão, Malheiro não tem pejo em distinguir mudanças na história e um visível progresso: embora este venha a se configurar nos seus melhores arranjos com a civilização moderna e os valores do cristianismo, o direito romano justinianeu ${ }^{54}$ representaria o ápice no tratamento dos escravos e na abolição de antigas distinções ou formalidades.

O sentido deste progresso - e, igualmente, o que servirá de medida para aquilo que Malheiro valorizará e o que desprezará na experiência jurídica romana relativa à escravidão - é o sentido mais favorável à liberdade. Segundo Malheiro, os juristas romanos sabiam que o escravo, apesar de uma coisa - uma propriedade por ficção, sua maior crítica aos demais aspectos do direito romano -, é também homem e pessoa. Ao longo do tempo, eles próprios passaram a asseverar que não havia legitimidade na escravidão, tomada contra naturam; já que, por equidade e por força do Direito Natural, omnes liberi nascerentur ${ }^{55}$. No capítulo do primeiro tomo destinado às regras de interpretação - guia ligeiro da hermenêutica aplicada à escravidão - Malheiro enumera alguns dos princípios ou regras gerais estabelecidos no Digesto, todos marcados pela interpretação em favor da liberdade ${ }^{56}$; reiterando que representam o espírito do Corpus Iuris Civilis a respeito da matéria, sobretudo, por conta das reformas de Justiniano e do Cristianismo inspirador. Diante disto:

Prescindindo, porém, deste histórico e da legislação respectiva, remontemos aos Romanos, de cujo Direito nos teremos de socorrer muitas vezes como subsidiário ao nosso, mas bem entendido, segundo o uso moderno, quando conforme á boa razão, ao espírito do Direito actual, ás idéias do século, costumes e índole da Nação (...) Como decidido a L. de 18 de

\footnotetext{
${ }^{53}$ MALHEIRO, Ensaio, Tomo I, p. 36.

${ }^{54}$ Tanto que Malheiro, ao falar do direito de Justiniano, opta por outra alcunha: Direito Novíssimo, aquele direito que mais se aproxima dos ideais em favor da liberdade, que mais abrandou antigas formalidades e interpretações nocivas com relação ao direito de escravidão.

${ }^{55}$ Justiniano, Inst. 1.5.pr.; Ulpiano, D.1.1.4.

${ }^{56}$ Entre as principais regras, todas extraídas e referenciadas do Digesto: "A liberdade é cousa sem preço, isto é, que se não póde comprar, nem avaliar em dinheiro"; "Nada há mais digno de favor do que a liberdade"; "A bem da liberdade muitas cousas se determinão contra o rigor do Direito"; "O favor da liberdade muitas vezes exprime a ideia mais benigna" "Sempre que a interpretação é duvidosa, deve decidir-se a favor da liberdade"; "No que for obscuro se deve favorecer a liberdade"; "Nas questões de liberdade deve ser preferido o escripto mais favorável a ella, quando mesmo não seja o mais moderno"; "Em igualdade de votos, deve-se julgar a favor da liberdade" "Do mesmo modo, quando as testemunhas forem contrarias e favoráveis em numero igual"; "Não póde a liberdade ser julgada por árbitros, e sim por Juizes de maior categoria"; "No conflito de um interesse pecuniário e da liberdade, prevalece esta"; "A sentença a favor da liberdade é irrevogável". Perdigão Malheiro sugere que as Ordenações, pelo mesmo espírito cristão, tendem também a esta tese da interpretação em prol da liberdade, apontando que, por exemplo: (i) muitas coisas são constituídas em favor da liberdade contra as regras gerais do Direito (Ordenações 4.11.4); (ii) que a escravidão é contrária à lei natural (Ord. 4.42); (iii) que a liberdade é do Direito Natural; (iv) que a prova incumbe aos que requerem contra a liberdade, sendo que está a seu favor uma presunção plena; (v) que que não há cobrança de alçada para interpor recurso em favor de uma causa sobre a liberdade. Cf. MALHEIRO, Ensaio, Tomo I, p. 63-66.
} 
Agosto de 1769 [= A lei da Boa Razão], e foi explicado pelos Estatutos da Universidade de Coimbra de 28 de Agosto de 1772.Teremos o cuidado de ir fazendo a aplicação que nos parece aceitável desse Direito; outros farão o mesmo; o pensamento é livre, e esta liberdade Em mesmo sentido: deve ser respeitada ${ }^{57}$.

$\mathrm{Na}$ adopção desses princípios do Dir. Rom., como legislação subsidiaria, devemos ter sempre em vista que se não opponhão à boa razão, ao nosso Direito consuetudinário, á índole do povo, ás idéias da época, aos princípios mesmo da humanidade e caridade christã, em semelhante materia ${ }^{58}$.

Fica claro, portanto, que para Malheiro o recurso ao direito romano parte da seguinte lógica: inicialmente, é um direito histórico e formativo de muitos povos europeus, incluindo Portugal e, por extensão, a colônia e Império brasileiros, razões pelos quais as próprias fontes jurídicas dessas nações (como as Ordenações) são melhor explicadas e compreendidas à luz do estudo da "legislação romana"; num segundo momento, no entanto, partindo da situação de facto da inexistência de outro corpo normativo robusto com relação à escravidão, reconhece-se a necessidade de apelo ao direito justinianeu como fonte subsidiária; tal ocorre, no entanto, não pela autoridade intrínseca do direito romano, mas, nos termos da Lei da Boa Razão, àquilo que o direito romano se mostra igualmente civilizado, moderno, em conformidade não apenas com as peculiaridades do povo romano que o criou, mas igualmente ao espírito do século XIX. Cabendo ao jurista decifrar esta "boa razão", fa-lo Malheiro buscando o direito mais favorável à liberdade: num tratado jurídico que se ocupa quase que pela metade a respeito dos modos de manumissão, a justa medida, aquela que permite identificar por que razão certas disposições de direito romano são aplicáveis e outras foram derrogadas pelo direito moderno - a mesma razão que explica por que o direito de Justiniano é considerado mais perfeito do que o direito romano mais antigo - é a posição mais favorável à liberdade, no que o direito romano subsidiário ou o direito pátrios nada mais fazem do que se aproximar de uma disposição natural.

Mesmo um leitor apressado do primeiro tomo do Ensaio perceberá, neste sentido, que todos os capítulos (e seus interiores artigos) são fundamentalmente cindidos em duas partes: na primeira, Malheiro se debruça sobre como os antigos (não apenas, mas com grande ênfase aos romanos) entendiam questões como a origem e o fim da escravidão, as formas de manumissão, o pecúlio ou os direitos dominicais; em seguida, passa em revista o que se passa "entre nós", isto é, o modo pelo qual o direito moderno trata da mesma matéria (recorrendo àquele quadro de fontes salientado supra, com largo uso das Ordenaçóes, alvarás, decretos e jurisprudência $)^{59}$ e em quê o direito romano é aproveitável como fonte subsidiária, quando ele é "inteiramente conforme á boa razão,

\footnotetext{
${ }^{57}$ MALHEIRO, Ensaio, Tomo I, p.93, acrescido da nota de rodapé n. 388.

${ }^{58}$ MALHEIRO, Ensaio, Tomo I, p. 115.

${ }^{59}$ V.g. MALHEIRO, Ensaio, Tomo I, p. 134: "Vejamos agora que applicação podem ter entre nós taes disposições [do Direito Romano]".
} 
e aceitável entre nós como fonte subsidiaria" ${ }^{60}$; "em tudo quanto tem de favorável (...) taes disposições, são ellas aceitáveis entre nós como Direito subsidiario"61.

O fiel da balança se dará sempre a partir da análise dos institutos jurídicos e do grau de proteção que dão ao princípio de favor à liberdade. Quando o direito romano se apresenta por demais "peculiar" - isto é, quando o que há de histórico suplanta o que há de racional; quando o direito do romano é, por assim dizer, romano demais, antigo demais, muito próprio de sua própria época, sem contornos a-temporais -, a linguagem elogiosa de Malheiro dá lugar a expressões como "ficções", "sutilezas", "legislação intrincada", "especialidades próprias daquele Povo e de seu direito", que se contrastam contra o que é a realidade do direito e trazem, inclusive, "confusão de

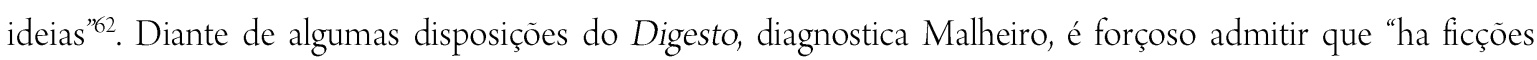
peculiares aos Romanos, que obstão a que sejão recebidas sem restricções taes decisões" ${ }^{\prime \prime 3}$. Mesmo o direito romano em determinadas matérias:

(...) offerecia graves difficuldades, devidas á organização peculiar do estado social, do elemento servil, aos seus costumes, e indole, assim como ás subtilezas e ncções desse Direito, tormentos dos seus legisladores e Jurisconsultos ${ }^{64}$.

Razão pela qual, por vezes, o vocabulário técnico forjado pelo mundo romano precise ser temperado, atualizado, corrigido e, em casos mais extremos, expurgado. O jurista deve estudar a história do direito romano e a sua própria para compreender a diferença de contexto e de princípios que guiavam o direito de escravidão da antiga Urbe e aqueles que regem os tempos modernos. Mesmo o "lacunoso" direito do legislador hodierno pode, por vezes, se melhor se adequar ao princípio de favor à liberdade, ser aquele digno de aplicação. Em complemento ao fragmento acima citado - está Malheiro se referindo à matéria do statuliber, ao qual voltaremos - é neste sentido sua assertiva:

Entre nós, essas razões de difficuldade desaparecem, em face da nossa organização social, das nossas idéas, usos e costumes, da índole do povo, do seculo e época em que vivemos, a até da nossa propria lei, que reprovou todas aquellas subtilezas e ficções, banindo-as do nosso Direito, e só permittindo seguir-se a legislação, Romana, nos casos omissos, pela boa razão em que ella se funde, ou em outros termos, segundo o uso moderno, o espirito do seculo ${ }^{65}$.

Um último ponto a ser salientado é que Malheiro está plenamente ciente do caráter constitutivo de tal

\footnotetext{
${ }^{60}$ MALHEIRO, Ensaio, Tomo I, p. 135.

${ }^{61}$ MALHEIRO, Ensaio, Tomo I, p. 143.

${ }^{62}$ MALHEIRO, Ensaio, Tomo I, p. 165. Quando, aliás, o estudo do direito romano é excessivo, o risco, para Malheiro, é justamente este: apegar-se àqueles institutos "fictos", que dizem respeito à "índole daquele povo", mas que é cego para a boa razão e o espírito do século XIX. Ao analisar, por exemplo, a questão dos efeitos jurídicos da manumissão com condição ou prazo, e em crítica àqueles que reconhecem a peculiaridade do statuliber, Perdigão Malheiro responde que aí estamos diante de um problema de vício de argumentação, "a confusão de idéias, por não se querer abandonar o terreno das ficções; as quaes muitas vezes conduzem a extremas consequências, que não confirmão os princípios, os quaes por conseguinte devem ser abandonados”.

${ }^{63}$ MALHEIRO, Ensaio, Tomo I, p. 151.

${ }^{64}$ MALHEIRO, Ensaio, Tomo I, p. 156.
} 
lógica jurídica. A existência de um "rol de fontes de direito" ofertada pelo legislador desde a reforma pombalina, bem como a indicação pelos Estatutos de Coimbra do que consistiria a boa razão, por si sós não asseguram nem (i) quais dispositivos daquele direito romano são aplicáveis, subsidiariamente, ao "nosso direito"; (ii) nem, tampouco, uma vez realizada tal indicação, um esquadro de antemão para a medida em que tais dispositivo ainda se aplicam em conjunção com as demais fontes de direito, tampouco fornece um guia de subsunção normativa. $\mathrm{O}$ trabalho do estudioso do direito, neste caso, não é nem o de exegeta das fontes jurídicas (romanas ou modernas), nem o de um simples compilador dos anais da história do direito: é um trabalho técnico de reconstrução do melhor direito, de uma estrutura jurídica que se aplica ao "espírito do século" e "à boa razão" e, por isto mesmo, é favorável à causa da liberdade:

É um trabalho de reconstrucção aquilo que vamos tentar; outros farão melhor, ou seguiráõ aquelle Direito [romano]. Prescindamos de todas essas ficções, anachronicas, obsoletas, sem applicação ao nosso estado, e vamos á realidade das cousas; investiguemos a verdade em toda a sua virginal e candida nudez. A analyse, e a applicação mesmo de certos. Princípios do Direito geral nos levaráó a salvamento, com um pouco de boa vontade a favor da liberdade (grifamos) ${ }^{66}$.

Percebe-se aqui, nitidamente, o tom professoral que não parece destoante de um leitor de Savigny ou do "direito dos professores" de Puchta, ainda que à serviço íntimo da Corte do Império. Estuda-se a história do direito romano, este "direito subsidiário" aplicado nas terras brasileiras desde há muito; no entanto, não por antiquarismo, mas na tarefa de compreender - e mais, compreender para aplicar - o direito hodierno, o direito de um dado estado de coisas, de um dado povo, que corresponde à dada realidade.

\section{“EM FAVOR DA LIBERDADE": A ALFORRIA NO ENSAIO}

Analisaremos nesta seção (3.1) a distinção entre as formas solenes e não-solenes de manumissão e a razão, para Perdigão Malheiro, de não subsistirem no direito pátrio; os modos (3.2) voluntários de manumissão, destacando a discussão a respeito de sua natureza jurídica (3.2.1) e o caso específico das alforrias fideicomissárias, condicionais ou com prazo (3.2.2); e, por fim, (3.3) a intrincada questão da natureza jurídica dos statuliberi.

\footnotetext{
${ }^{65}$ MALHEIRO, Ensaio, Tomo I, p. 156. Aliás, uma vez que as "legislações das nações modernas" também eram consideradas uma fonte subsidiária a ser levada em conta na aplicação do direito, Malheiro destaca este mesmo princípio para a legislação sulista dos Estados Unidos (Opus cit, p. 167).

${ }^{66}$ MALHEIRO, Ensaio, Tomo I, p. 162-163.
} 


\section{Distinção entre formas solenes e não-solenes na aquisição/manumissão: a liberdade guiando o progresso}

A escravidão da história antiga encontrava seu fundamento jurídico nas guerras: entendia-se que, por ius gentium, a sujeição do perdedor ao cativeiro e ao domínio do vencedor era um avanço. Destaca, no entanto, que ao longo de sua história o próprio direito romano passaria a compreender, no entanto, que a escravidão é um instituto contra naturam, introduzido pela ferocium hostium (Ulpiano, D.1.1.4). De modo que a escravidão existe: este é um fato histórico, desde a Antiguidade até o Brasil de seu tempo, ainda que aquela causa originária que fundamentasse a escravidão antiga - a guerra - não seja mais a causa primordial no caso da escravidão do século XIX, mas sim, sua mantença pelas leis positivas.

Diante disso, Perdigão Malheiro enuncia os modos pelos quais os romanos entendiam ser legítimos modos de tornar alguém escravo: (1) uma guerra justa, nos termos do antigo ius gentium (Marciano, D.1.5.5.1; Ulpiano, D.49.1.24); (2) deixar um cidadão de se inscrever no censo lustral a cada quinquênio, tornando-se escravo público (Ulpiano, Regulae 11.11); (3) o roubo em flagrante, quando era o ladrão entregue como escravo ao ofendido (Gaio, Inst. III.189; Lei da XII Tábuas, tab. 8a); (4) a escravização do devedor insolvente pelo credor (Lei das XII Tábuas, tab. 3a); (5)d-se alguém vender como escravo contra a proibição da lei, com o fito de fraudar o comprador, desde que não incidisse certas cláusulas que barrassem a escravidão; (6) a mulher livre que tivesse contubernium com escravo, após advertida três vezes pelo senhor do escravo [S.C. Claudianum]; (7) aquele que era condenado à pena de morte ou a outros suplícios, meio ficto pelo qual a lex Porcia encontrou para conciliar a ideia de que um cidadão romano não poderia ser açoitado nem sofrer pena de morte; (8) o nascido de mãe escrava, seguindo o ventre da mãe (Celso, D.1.5.19; D.1.5.5.2; D.1.5.24); (9) a ingratidão do liberto, obtida por sentença, que o tornava novamente escravo (Justiniano, Inst. 1.16.1).

Destaca, no entanto, que este é um rol que incluía muitos modos de escravização que caíram em desuso até a época de Justiniano, "o propugnador mais acérrimo da causa da liberdade" ${ }^{\text {"67. }}$. Aos seus olhos há um evidente progresso: anteriores fontes ou fundamentos da escravidão deixam de sê-lo na história; como o caso mesmo da guerra. Reminiscências - eles as chama de vestígios -, admite, existem nas Ordenações Afonsinas ou Filipinas, mas "nada disto tem hoje applicação, mesmo em nosso Direito actual”ø8. Isso dá azo para o argumento de Perdigão Malheiro: a escravidão se mantém existindo, mas é infundada; sua única razão de existir é, por um lado, o ilegítimo tráfico (que é "tolerado pela ordem pública", mas não cria justo título) e, por outro, ainda legitimado nas fontes do direito, o nascimento. O princípio regulador para tal é o partus sequitur ventrem (no que Perdigão opta

\footnotetext{
${ }^{67}$ MALHEIRO, Ensaio, Tomo I, p. 38.

${ }^{68}$ MALHEIRO, Ensaio, Tomo I, p. 40.
} 
por não citar as fontes romanas, mas sim, normas modernas $\left.{ }^{69}\right)$. A regra ao longo do direito romano, explica o autor, acabou por ganhar a seguinte interpretação: se em algum momento entre a gestação e o parto a mãe foi livre, o filho nascerá livre e ingênuo ${ }^{70}$.

\section{Terminação voluntária do cativeiro: o conceito de manumissão}

A partir da terceira seção do Capítulo III (O Escravo ante a Lei Civil), Malheiro inicia o tratamento das formas de findar a escravidão. O excurso histórico romano e pátrio serve, em todos os momentos, de guia para interpretar juridicamente a manumissão.

Começando, como usual, pelo direito romano e, neste ponto, a ele se mantendo, Perdigão Malheiro destaca que existem três formas de fazer cessar a escravidão: (1) a morte natural, (2) a manumissão ou alforria ${ }^{71} \mathrm{e}$ (3) disposição legal a esse respeito ${ }^{72}$. Em seguida, debruça-se sobre a divisão, tipicamente romana, entre dois métodos distintos de obter a liberdade em Roma: os métodos solenes, típicos do domínio quiritário sobre o escravo, e os métodos não-solenes, que regiam o domínio bonitário, que foram surgindo ao longo da história ${ }^{73}$. A distinção entre modos solenes e não-solenes de manumissão se explicava por uma típica peculiaridade do povo Romano, a existência de diferentes stati ou graus de concessão de direitos citadinos entre os indivíduos: assim, a divisão entre duas formas de manumissão diferenciava os libertos que se tornariam cives romani (manumissão por métodos solenes), titulares das prerrogativas do ius civile da República romana, e aqueles que se tornariam

\footnotetext{
${ }^{69}$ Como a Lei de 6/6/1755, que extinguia a escravidão indígena e de seus descendentes; e o Alvará de 10/03/1682: “(..) Pela mesma razão serão cativos todos aquelles que o erão antes de irem para os mesmos Palmares, como também os filhos e descendentes de mulheres cativas, seguindo o parto e a condição do ventre" (MALHEIRO, Ensaio, Tomo III, Apêndice, p. 4). Note-se, naturalmente, que o objetivo de Malheiro aqui é simplesmente demonstrar que o princípio sequitur ventrem já era aplicado e conhecido em terras brasileiras e lusitanas há muito.

${ }^{70}$ Ao que ele acrescenta que existiriam casos em que mesmo com a mãe escrava em todo esse período, o filho nascerá livre e ingênuo, como, por exemplo, se fosse filho do dominus da escrava, sendo contrário ao Direito Natural que um pai seja senhor do próprio filho; o Direito Romano também aquiescra com essa tese quando, com Diocleciano, proibiu a venda dos filhos pelo pai e, implicitamente, negando-lhe domínio do filho. Cf. MALHEIRO, Ensaio, Tomo I, p. $42-44$.

${ }^{71}$ Chamada de direta quando direcionada a escravo próprio e em testamento; e fideicomissária se deixada como uma obrigação a ser cumprida pelo herdeiro.

${ }^{72}$ MALHEIRO, Ensaio, Tomo I, p. 92: "Todos os povos, antigos e modernos, hão consagrado com mais ou menos latitude a faculdade de extinguir-se a escravidão por manumissão ou alforria, e por disposição da lei. Além dos Judeos, os Gregos sobretudo os Athenienses, os Romanos, na antiguidade, nos ministrão exemplos irrecusáveis; e nos tempos modernos, todas as Nações Christãs, cuja legislação se foi modificando, a ponto de abolirem a escravidão, e até mesmo a servidão; de sorte que, hoje, se póde asseverar que em terras de Christãos não há escravidão senão no Brasil, e algumas possessões de Portugal e Hespanha”. Cf. WEHLING, 2009, p. 392-396.

${ }^{73}$ Eram três os métodos solenes: (1) através do Censo quinquenal, com o imperador Constantino substituído pela manumissão solene ante a Igreja; (2) pela vindicta, ato formal e solene que, aos poucos, perderia seus contornos mais formais; (3) pelo testamento. Já entre os métodos não-solenes, as formas de manumissão (1) per epistolam, (2) inter amicos, (3) per convivium, (4) per nominationem ou (5) qualquer modo que deixasse a intenção de libertar clara, tácita ou conjecturalmente (MALHEIRO, Ensaio, Tomo I, p. 93-97).
} 
latini ou latini-juliani (através da manumissão por métodos não-solenes). Importante notar, salientava Malheiro, que tais distinções foram abolidas pelo "Direito Novíssimo" de Justiniano.

E é assim que, novamente, fica evidente a operação de depuração através do qual o jurista, após estudar um aspecto histórico do direito romano antigo, percebe que este não se encaixa à sua realidade social; é ao direito romano à época de Justiniano que se deve buscar orientação, não, no entanto, por uma autoridade "em si", mas pelo ajuste desta legislação ao mesmo "espírito" que orienta o direito pátrio hodierno. Assim:

Do que fica exposto se deve concluir que, entre nós também, não há nem deve haver differença essencial nos modos de manumissão. Nem temos essa variedade de libertos, de que démos notícia em relação a Roma até o tempo de Justiniano. Por qualquer modo, pois, que a liberdade seja conferida ao escravo, solemne ou não, directa ou indirectamente, expressa ou tacitamente ou mesmo em fórma conjectural ou presumida, pro actos entre vivos ou de ultima vontade, por escripto publico, particular, ou ainda sem eles, a liberdade é legitimamente adquirida; e o escravo assim liberto entra na massa geral dos cidadãos, readquirindo a sua capacidade civil em toda a plenitude, como os demais cidadãos nacionais, ou estrangeiros (grifou-se $)^{74}$.

O jurista, portanto, procede com uma lógica de apresentação e argumentação precisa que se repete ao longo do Ensaio. Inicialmente, retrata a história do direito romano - não meramente por ser, tal qual o latim, "fina e última flor do Lácio", mas por ser a fonte mais abundante a respeito daquele direito até seu tempo -, analisando a trajetória dos modos de manumissão, demonstrando seu vocabulário, sua tecnicalidade e, principalmente, suas mudanças ao longo do tempo. Concluindo a própria história, pois, por uma abolição da distinção entre modos solenes e não-solenes de manumissão, bem como, com o tempo - está ele aqui a pensar em Justiniano -, à própria distinção entre diferentes stati de liberti, o passo de Perdigão Malheiro é afirmar: cá, tal qual acolá. E isto se dá por razões: (i) tal qual no contexto justinianeu, não existe, no Brasil, uma diferenciação de espécies no genus "liberto" que justifique uma distinção nos modos de manumissão; (ii) mostrou o próprio desenvolvimento do direito romano a tendência para dirimir as solenes que separavam uns modos de outros, seja quanto ao tipo de domínio, seja quanto às formalidades necessárias para configurar manumissão em sentido técnico; (iii) motivo para o quê as três formas de manumissão existentes em solo pátrio apontados por Perdigão Malheiro - carta independente de testemunhas, testamento ou codicilo, o batismo ${ }^{75}$ - sejam, na configuração histórica delineada pelo jurista, uma longa manus da mesma história das formas de manumissão, obedecendo, assim, aos mesmos critérios.

Uma vez exposta a indistinção entre métodos de manumissão, Malheiros passa, stricto sensu, ao instituto propriamente dito. Manumissio ou alforria, define, é o ato voluntário do senhor para restituir o escravo à liberdade, seja por ato entre vivos ou por morte, "protegida pelas leis com inúmeros favores", citando tanto o antigo Digesto de Justiniano quanto as Pandectas de Pothier. A forma é indiferente: solene ou não solene o ato não será nulo nem

\footnotetext{
${ }^{74}$ MALHEIRO, Ensaio, Tomo I, p. 97.

${ }^{75}$ MALHEIRO, Ensaio, Tomo I, p. 98.
} 
terá prejudicada "as liberdades nelle [o ato] conferidas], se poderem manter-se por algum outro fundamento", admissível toda forma de prova.

A interpretação em prol da liberdade seria tamanha que mesmo a regra geral de que só se alforria escravo de quem se possui domínio poderia ser relativizada em alguns casos, podendo-se dispor de escravo alheio: (i) se o escravo foi vendido (ou doado a título gratuito) com cláusula de ser libertado pelo comprador, e, coagido ou não por sentença a cumprir a cláusula, tornando-se patrono do liberto; (ii) disposição de última vontade sobre o escravo alheio em testamento, entendida como fideicomissária (que será objeto de análise mais alongada infra, item 3.2.2); (iii) quando herdeiro, legatário ou beneficiário de doação aceita legado/doação com a cláusula de liberdade; (iv) se o senhor se satisfaz com o preço do escravo.

\section{A natureza jurídica da manumissão}

No mesmo passo em que Perdigão Malheiro fala da necessidade da operação de uma "reconstrução" por sobre o direito romano, despindo-se de suas ficções para chegar à "realidade das cousas", alcança-se uma discussão técnica relevante da civilística a respeito do tema. A matéria da alforria ou manumissão, tanto no direito romano (v.g. Justiniano, Inst. 1.3.2 - est datio libertatis) quanto nas Ordenações Filipinas (Livro 4º, Tit. LXIII) encontrava-se ordenada dentro do tema da doação; também normas como o Regulamento n. 2.708 de 15.12.1860 utilizavam como sinônimo de "alforria" a expressão "doações de liberdade. Desta conjuntura revela-se a quaestio iuris em tela: o que efetivamente se passa, técnica e juridicamente falando, quando um senhor manumite seu escravo?

A resposta de Malheiro para a quaestio - a alforria é uma doação? - será negativa. Se a alforria fosse doação, coloca o jurista, deveria haver (i) objeto e (ii) sujeito/adquirente. Uma análise jurídica séria desse instituto, ao seu ver, deixa muito claro que seria impossível à manumissão cumprir os requisitos desse tipo contratual, uma "ficção quasi pueril" considerar que o escravo é, enquanto escravo, possível adquirente da própria liberdade, e que a liberdade é um objeto transigível de contrato, e não, como na realidade, reflexo da liberdade que por direito natural sempre the pertenceu e apenas the retorna por ocasião da alforria ${ }^{76}$. Na verdade, o jurista destaca que uma análise técnica mais sofisticada permitirá evitar confusões com outros institutos de direito civil. Não sendo doação, a alforria tampouco é legado, mesmo quando feita por ato de última vontade, também sendo isenta da taxa. Também não é um contrato de compra e venda, mesmo quando a título oneroso, igualmente isenta de "siza ou imposto", nem uma simples transferência de propriedade, pelo qual permanece, à revelia daquela,

\footnotetext{
${ }^{76}$ MALHEIRO, Ensaio, Tomo I, p. 162; por esta mesma razão, acrescenta ele ainda, uma circular estabeleceu que a alforria é isenta de imposto.
} 
"isenta do sello proporcional". Supra lidaremos particularmente com o tratamento jurídico do statuliber em Perdigão Malheiro: por agora, cumpre assinalar que igualmente não se trata de usufruto, mesmo quando um statuliber tenha sido manumitido com alguma condição a cumprir ${ }^{77}$.

É da análise das fontes romanas - mas, bem entendida, uma análise que deixa de lado eventuais sutilezas e ficções aplicáveis só àquele povo - que a solução jurídica mais precisa surge como uma renúncia do dominium e do poder que o senhor tinha por sobre o escravo. Num arranjo que engloba várias fontes - o jurisconsulto Ulpiano (D.1.1.4), as Ordenações (Livro 4ํ, Tit. XLII) e o Alvará de 30 de Julho 1609 - a conclusão de Malheiro é que:

A verdade, a realidade das cousas, á parte as ficções, é a que se lê em outros textos, onde se diz manumittere, de manû missio, de manû dare, em contraposição a manû capere. A alforria era entre os Romanos denominada manumissio; e entre nós igualmente manumissão, emancipação. Com efeito, em semelhante acto o senhor nada mais faz do que demitir de si o domínio e poder que tinha (contra direito) sobre o escravo, restituindo-o ao seu estado natural de livre, em que todos os homens nascem. A alforria não é, portanto, em sua última, única e verdadeira expressão, mais do que a renuncia do direito do senhor sobre o escravo, e a consequente reinetegração deste no gozo de sua liberdade, suspenso pelo facto de que elle foi victima; o escravo não adquire, pois, rigorosamente a liberdade, pois sempre a conservou pela natureza, embora latente (permitta-se o termo) ante o arbítrio da lei positiva. Eis o que o profundo e analytico Savigny, demonstra á evidencia no seu magno tratado do Direito Roman. Doutrina consagrada em várias disposições do nosso Direito moderno. Desde que, portanto, a manumissão tem lugar, quer por acto entre vivos, quer de ultima vontade, o escravo deixa ele de o ser, para readquirir, mesmo ante a lei, o seu estado natural de homem, com toda a sua liberdade, e consequente capacidade civil ${ }^{8}$.

Como salienta em nota de rodapé, "liberto se lê feito livre, desobrigado de ônus"79; em termos de natureza jurídica (ou, o termo por ele preferido, "sua última, única e verdadeira expressão"), Perdigão Malheiro define a alforria, então, como simples renúncia dos direitos do senhor sobre o escravo, reintegrando-o ao gozo da liberdade que sempre the pertenceu por direito natural (e permanecia latente), mas estava suspensa de fato diante do arbítrio da lei positiva ${ }^{80}$, recuperando, além disso, sua capacidade civil; nem importa se a manumissão se teu por ato entre vivos ou de última vontade. Poderíamos dizer de outro modo: para Malheiro, a alforria é desconstituição da propriedade ("ficta", por sobre uma pessoa), não a constituição de uma nova relação jurídica, não uma aquisição ou troca ${ }^{81}$.

\footnotetext{
${ }^{77}$ MALHEIRO, Ensaio, Tomo I, p. 164, nota 679.

${ }^{78}$ MALHEIRO, Ensaio, Tomo I, p. 163-164. Além de Savigny, Malheiro aponta que este é o entendimento de Pothier e, entre os juristas pátrios, Teixeira de Freitas.

${ }^{79}$ MALHEIRO, Ensaio, Tomo I, p. 162, nota 673.

${ }^{80}$ MALHEIRO, Ensaio, Tomo I, p. 163, nota 677: "Fora da lei positiva não é possível comprehender-se a existência da escravidão (Lord Mansfield)".

${ }^{81}$ Com o quê Teixeira de Freitas concordaria na terceira edição da Consolidação: mesmo se-deve dizer das alforrias, por não serem propriamente doações — Man. do Procur. dos Feitos $\$ 561$, e Not. 1182. Vid. Not. ao Art. 42. Não são propriamente doações (Savigny Trat. de Dir. Rom. $\$ 148$ ), porquê uma das partes abandona uma porção de seus bens, e a outra adquire um direito, que não é patrimonial, adquire sua liberdade. Sem duvida (palavras do cit. Savigny) o senhor, que liberta um escravo, sacrifica por
} 
Para dar alforria, em regra, o manumissor deveria ter capacidade e livre disposição de seus bens. É o que justificava desde o direito romano que não pudessem livremente alforriar: (i) os escravos (que não possuíam capacidade civil, não podendo representar o senhor em um ato jurídico desta monta), (ii) os infantes (conquanto incapazes de exprimir vontade), (iii) o tutor, curador e outros quanto aos escravos do tutelado (que não possuem a faculdade de alienar dentro da sua atividade de administração), (iv) o pupilo ou a pupila impúberes e (v) o usufrutuário (que não tem plena disposição do bem).

\section{A liberdade fideicomissária, condicional ou pendente prazo}

Embora sejam figuras jurídicas distintas e combináveis entre si - fideicomisso, condição e prazo ou termo -, no que tange à sua presença na alforria voluntária do escravo, esses instintos possuem um tratamento similar em Perdigão Malheiro, a partir do princípio daquilo que mais favorece à liberdade, e, metodologicamente, da necessidade de adaptação das fontes jurídicas subsidiárias à boa razão.

Comecemos por definições de época que faziam parte da literatura jurídica de formação de Malheiro. Trigo Loureiro definia o fideicomisso como "disposição, pela qual o testador manda ao seu herdeiro que entregue á certa pessoa, e a tempo certo, a universalidade da herança ou somente certa quota-parte, ou certa cousa da mesma herançą" ${ }^{\not 2}$, acrescentando que passa então o herdeiro, agora fiduciário, a transferir a herança ou parte dela ao fideicomissário, nos termos dispostos pelo testador. Os fideicomissos - entendidas assim como marcas jurídicas que gravam um bem -, tais quais os legados, são suscetíveis genericamente à condição ou prazos impostos pelo testador, desde que possíveis e lícitas.

O instituto dos fideicomissos - bem como o dos legados - não apresentava, por si, nenhuma grande dificuldade (ou novidade) na tratadística de direito civil ou numa obra como a Consolidação de Teixeira de Freitas. No entanto, ganha contornos jurídicos e problemas mais específicos quando, combinada com o instituto jurídico da alforria (e em oposição à alforria direta, mesmo quando testamentária), formava a alforria

liberalidade uma propriedade verdadeira, e desse lado verificão-se as condições essenciaes da doação. O escravo libertado recebe o maior beneficio, que um homem pode fazer á outro, porem o senhor não transmitte ao libertado a propriedade do escravo. Esta propriedade fica completamente anniquilada, e a alforria cria um homem livre, um sujeito capaz de direitos. A alforria testamentaria, ou entre vivos, não era doação, e nunca se-lhe-applicou a insinuação. Se no Direito Romano se-a-tem chamado donatio, é no sentido impróprio da palavra”. Cf. TEIXEIRA DE FREITAS, Consolidação, Tomo I, p. 295-296 (3ª ed., nota ao art. 411). Desde a segunda edição, no entanto, o civilista se permitia fazer analogia entre os institutos: "Como a alforria gratuita tem analogia com a doação, considerada esta como acto unilateral antes de aceita pelo donatário, e como acto bilateral depois de acceita; segue-se, que as cartas de alforria por fallécimento do senhor, achadas entre seus papeis, sem que dellas tivessem conhecimento os escravos libertados, não produzem effeito senão depois do fallécimento. Os filhos pois de uma escrava libertada nestas cirscumstancias, nascidos antes deter a carta de alforria produzido seus effeitos, antes de sêr conhecida, como sé tivesse in mente reposta, são escravos" Cf. TEIXEIRA DE FREITAS, Opus cit, p. 285.

${ }^{82}$ LOUREIRO, Instituições, Tomo II, p. 14. 
fideicomissária. É o próprio Malheiro quem justifica destinar tamanhas atenções e destaque para este instituto: isto se dá por força do próprio direito romano que, nesta matéria sucessória, era "muitissimo complicada, pela índole desse Direito, e organização daquelle pôvo", fazendo referência ao Digesto (livro 40, tít. 3), à obra de Pothier e às Consolidações das Leis Brasileiras, e explicitando:

Entre nós muitas dessas dificuldades desaparecem, tendo-se em atenção o systema e índole de nossa legislação, nossos costumes e idéas, e sobretudo a organização muito mais simplificada do elemento servil da nossa sociedade e época. Todavia a materia não deixa de ser melindrosa; e em geral teremos de socorrer-nos daquela legislação que na deficiência quase absoluta da nossa ${ }^{83}$.

À época da escrita do Ensaio, nem mesmo Teixeira de Freitas havia explicitado o tratamento do tema combinando direito subsidiário e direito pátrio - da alforria fideicomissária ${ }^{84}$, condicional ou a prazo tal qual ela deveria ser entendida no ordenamento jurídico brasileiro; igualmente, como Malheiro antes dele, iria se servir do direito romano para a reconstrução do instituto.

Pelo direito romano, informa Malheiro - começando, como sempre, por sua revisão histórica dos institutos -, o fiduciário (aos olhos romanos, o real encarregado de dar a liberdade ao escravo, não o testador) era proprietário do escravo até manumiti-lo, tornando-se seu patrono. Proprietário "ficto" que era, podia até mesmo alienar o escravo, ainda que o adquirente permanecesse obrigado a libertá-lo (como um encargo; a res permanecia gravada); o escravo poderia mesmo exigir que o fiduciário o resgatasse e libertasse, para que fosse ele seu patrono $^{85}$. Por regra e sempre que em questão de dúvida, coloca Perdigão Malheiro, o direito romano atendia a favor da liberdade também na alforria fideicomissária, inclusive se fosse necessário suprir a capacidade do fiduciário ${ }^{86}$, ou diante de sua falta ou culpa, numa miríade de hipóteses previstas no mesmo título do Digesto - em muitos casos, o magistrado ou o juiz supririam ou concederiam aquilo que fosse necessário para, em respeito à vontade do testador e em prol da liberdade por ele manifestada, seguindo uma regra geral expressa por Marco Aurélio ${ }^{87}$.

"Em nosso direito" é cabível tudo que seja "favorável à liberdade” e não recaia nas "ficções" típicas do

\footnotetext{
${ }^{83}$ MALHEIRO, Ensaio, Tomo I, p. 146.

${ }^{84}$ Quando definiria: "O testador póde conferir alforria fideicommissaria á seus próprios escravos, ou á escravos alheios; ainda que estes não sejão do herdeiro á quem institue, ou de legatário á quem deixa alguma coisa - L. 16. Dig. de fidei. libert." cf. TEIXEIRA DE FREITAS, Consolidação, Tomo II, p. 654 (nota da 3a edição ao art. 42).

${ }^{85}$ D.40.5.13.; D.40.5.20; D.40.5.26.

${ }^{86}$ Em entendimento menos aferrado às fontes romanas que o de TEIXEIRA DE FREITAS, Consolidação, Tomo II, p. 655 (nota da $3^{a}$ edição ao art. 42). Igualmente: se, para Teixeira de Freitas, a mera expressão "eu vos recomendo um escravo" não configura alforria fideicomissária, para Malheiro, dever-se-ia tomar em conta ambos os princípios: a vontade do testador, típico do direito sucessório, combinado com o favor da liberdade, que é prioritário em caso de dúvidas no momento de aplicação da norma, cf. MALHEIRO, Ensaio, Tomo I, p. 148-150.

${ }^{87}$ D.40.5.30.16: fidei-commissariae libertates neque aetate, neque conditione, neque mora non praestantium, tardiusve redeuntium, corrumpi, aut iu deteriorem statum perduci.
} 
povo Romano ${ }^{88}$. Malheiro esmiuça tais peculiaridades numa sequência lógica: (1) no direito romano, por conta dos direitos do patrono, a liberdade era entendida como originária do fiduciário (proprietário 'ficto'), não do testador; aos tempos de Justiniano, no entanto, tais sutilezas e ficções teriam sido abandonadas, entendendo-se que o verdadeiro patrono era o testador ${ }^{89}$; (2) não havendo tais sutilezas típicas do direito romano no direito brasileiro moderno, tais libertos devem ser reputados sem patrono; (3) a liberdade se deve assim à morte testamentoris; (4) os filhos das escravas nascidos nesse tempo, seguindo a doutrina de Marciano sobre o ventre, são livres e ingênuos; as aquisições de tais libertos são todas legítimas; (5) Tais libertos não estão em condição servil, como o próprio direito romano o reconheceria ao final de sua trajetória.

Neste esquema de coisas, o fiduciário poderia ser simples executor da vontade do senhor ou, mais comumente, possuir ius utendi ou ius usufruendi do escravo, isto é, dispor de direito aos serviços do liberto por algum tempo, se isto tiver sido determinado pelo testamentário. Para Perdigão Malheiro - alguém a favor do fim do instituto da escravidão, mas muito mais um gradualista do que um abolucionista da mesma feição de Nabuco - tal condição "não é incompatível com a liberdade, nem impede as acquisições que ao liberto possão vir nessa época ${ }^{x 90}$; é, no entanto, um direito (aos serviços do liberto) de tipo pessoal e intransferível, que mesmo que incluía um fecho longo (como servir a outrem por muitos anos), deve se concluir com a liberdade.

A manumissão fideicomissária, embora mais aplicável a escravo próprio, também podia se dar sobre escravo alheio. Quando o escravo libertado fideicomissariamente era do herdeiro ou legatário, aceitar o legado ou herança implicava simplesmente em aceitar cumprir tal vontade do testador. Se o escravo era de outrem, importava ao fiduciário empregar todos os meios legítimos para adquirir e libertar tal escravo. A tal ponto que, sob Alexandre Severo, entendeu-se que nos casos que o senhor do escravo não o queira vender, ao invés de caduco o fideicomisso (e a liberdade), ficava apenas adiada e não-extinta a obrigação. Nestes casos, o Magistrado era a de conhecer os motivos que impedissem o fiduciário de cumprir a vontade do benfeitor, declarando livre o escravo se ele o devesse ser. Da alteridade histórica, passando pelo crivo da "boa razão" à conclusão: "os princípios expostos são aceitáveis entre nós pela boa razão em que se achão fundados ${ }^{x 91}$.

São estas mesmas considerações - a compatibilidade dos institutos de direito civil com a "boa razão" e o "espírito do século", englobando o favor à liberdade - que fundamentam a posição de Malheiro a respeito de

\footnotetext{
${ }^{88}$ MALHEIRO, Ensaio, Tomo I, p. 134, citada supra no texto.

${ }^{89}$ MALHEIRO, Ensaio, Tomo I, p. 151-152: “A realidade e verdade é, porém, em contrario; por quanto é o senhor quem demite de si o seu dominio e poder sobre o escravo, quando o manumite mesmo fideicomissariamente; por fórma que, ainda entre os Romanos, a lei vinha em auxilio do liberto, tirando até ao fiduciário em muitos casos os direitos de patrono, como já vimos, declarando que se devião reputar diretamente manumitidos pelo testador ou originário senhor. Demais, segundo a theria geral do Direito Romano novíssimo ou de Justiniano, essas diferenças de legado e fideicomissio, e outras subtilezas semelhantes forão abolidas; de modo que se deve entender que a alforria vem diretamente do testador ou bem-feitor senhor, e não do fiduciario".

${ }^{90}$ MALHEIRO, Ensaio, Tomo I, p. 153.
} 
condições e prazos para as alforrias ${ }^{92}$, dois tipos de elementos acidentais dos atos jurídicos particularmente relevantes para as manumissões. Desta feita, mesmo que se possa partir da classificação geral de tais institutos como o direito romano os esboçou, é preciso se subsidiar de um uso moderno e condizente de tais institutos (subsidiando-se, novamente, de autores como Savigny e Pothier para avançar suas posições).

Condição, tradicionalmente, entende-se como a vinculação a um acontecimento futuro e incerto para que uma relação jurídica se constitua ${ }^{93}$. Malheiro não tem problema com as tradicionais divisões entre condições ou cláusulas (i) positivas ou negativas ${ }^{94}$; e entre (ii) casuais, potestativas e mistas ${ }^{95}$; (iii) possíveis e impossíveis (estúltimas, nulificando o ato ${ }^{96}$. É uma quarta divisão, no entanto, que recebe sua atenção: aquela entre condições suspensivas e resolutivas que, respectivamente, define Malheiro, "e' aquella que adia ou dilata apenas a acquisição ou exercício de um direito, que assim fica dependente da condição" e "e' aquella que extingue o direito ou obrigação ${ }^{297}$. Apenas a primeira, para o caso da alforria (fideicomissária ou não) é válida. A condição suspensiva é admissível no direito relativo às alforrias, explica Malheiro, por ofertar ao escravo uma situação jurídica melhor, tornando-o aquilo que em direito romano se chamava statuliber ${ }^{98}$. Por sua vez, a condição resolutiva é nula ou, pelo absurdo, seria necessário cogitar a hipótese de uma liberdade que fosse revogável, algo incompatível com a própria ideia de liberdade (e o axioma libertas semel data non revocatur).

O mesmo quanto ao prazo ou termo (dies), definido como a época que faz depender o direito ou a

\footnotetext{
${ }^{91}$ MALHEIRO, Ensaio, Tomo I, p. 155.

${ }^{92}$ MALHEIRO, Ensaio, Tomo I, p. 139-145.

${ }^{93}$ RIBAS, Curso, Tomo II, p. 373 ss.

${ }^{94}$ Possuem por objeto a existência ou inexistência de um fato. RIBAS, Curso, Tomo II, p. 374 375; MALHEIROS, Ensaio, Tomo I, p. 139-140.

${ }^{95}$ Condições casuais dependem da alea, da sorte; as condições potestativas dependem unicamente da vontade; as condições mistas, de ambas. RIBAS, Curso, Tomo II, p. 376-378.

${ }^{96}$ RIBAS, Curso, Tomo II, p. 378-391; MALHEIRO, Ensaio, Tomo I, p. 141-142 e notas 387-388; a condição impossível em atos de última vontade, afirma Malheiro, entende-se por não-escrita, valendo sempre, em caso de dúvida, o favor da liberdade.

${ }^{97}$ MALHEIRO, Ensaio, Tomo I, p. 140. Ribas assim tratava: "Esta classificação, geralmente admittida pelos Jurisconsultos modernos, funda-se na diversidade do effeito que a condição tem de produzir, Assim, a condição suspensiva tem por fim criar um direito; emquanto a resolutiva tem por fim extinguir, ou rescindir, um direito”, cf. RIBAS, Curso, Tomo II, p. 392. Ribas faz uma distinção em três fases ou momentos: (i) a fase em que a condição ainda está pendente de cumprimento (pendet de conditio), havendo apenas possibilidade ou eventualidade de criação do direito, obrigação ou relações jurídicas, sendo assim inexigível, mas não podendo a outra parte frustrar sua possibilidade; (ii) a fase em que a condição foi realizada, formando a relação jurídica e os efeitos que dela emanam, retroagindo à data da convenção ou ato jurídico, inclusive, em caso de testamento, desde o momento da abertura da sucessão com a morte do testador; (iii) uma fase distinta, quando se torna certo que um dado acontecimento, que é condição, não mais se pode realizar (deficit conditio), cf. RIBAS, Opus cit, p. 394401. Igualmente, a respeito da definição, veja-se Loureiro: "No legado e fideicommisso deixado debaixo de condição suspensiva, o legatario e o fideicommisso adquirem logo desde a morte do testador direito resoluvel ao legado, e fideicommisso, e transmittem esse mesmo direito á seus herdeiros, se fallecem antes de verificar-se a condição; excepto, se estes não podem satisfazer a condição potestativa, como quando esta é pessoal; Cod. da Pr.p, 1, tit. 4, arts. 161 e 162, e tit. 12, art. 485; ou se do testamento constar que outra foi a vontade do testador; Valasc. Cons. 171, n. 9", cf. LOUREIRO, Instituições, Tomo II, p. 17.

${ }^{98}$ Ao que acrescentaria depois Teixeira de Freitas: "O escravo, á quem se-tem deixado liberdade debaixo de condição, emquanto esta pende, só debaixo delia pôde ser vendido”, cf. TEIXEIRA DE FREITAS, Consolidação, Tomo II, p. 653 (3a ed., nota ao art. $1.128)$.
} 
obrigação para extingui-lo ou resolvê-lo9", e a divisão entre prazo in diem ou ex die ("a partir da data") e ad diem ("até o termo"). O prazo in diem é admissível em alforrias na medida em que "não havia impedimento ou absurdo em que o escravo só começasse a gozar da liberdade ou fosse plenamente livre desde certa época"100, enquanto o prazo ad diem era tido por nulo (não-escrito) já pelo direito romano (Paulo, D. 40.4.3-4: libertas ad tempus dari non potest) uma vez que, como salientaram os romanistas modernos, extraindo do material histórico o princípio racional da regra, uma vez "dada a liberdade, ninguem podia fazel-a cessar e reviver a escravidão limitando a época ou o termo finalp101.

Como já observamos, tão logo a alforria tenha lugar, é ato jurídico que passa a ter plenos efeitos. Tão logo a manumissão se dê, seja como esta se dê, o escravo deixa de ser escravo, e readquire tal estado natural do homem. E a condição, e o prazo, que ocorrem nos contratos ou atos entre vivos? Alguns juristas, admite Malheiro, diriam que o escravo permaneceria escravo até que se alcance o prazo ou se implemente a condição. Perdigão Malheiro responde que aí estamos diante de um vício de argumentação, "a confusão de idéias, por não se querer abandonar o terreno das ficções; as quaes muitas vezes conduzem a extremas consequências, que não confirmão os princípios, os quaes por conseguinte devem ser abandonados"102. O termo ou a condição não obstam à aquisição do direito, apenas adiando ou suspendendo até o cumprimento da obrigação o seu exercício pleno e gozo; o direito está adquirido de tão logo, sendo até transmissível aos herdeiros. $\mathrm{O}$ fato de o direito romano antigo não considerar tal princípio nas disposições de última vontade, destaca o autor, não impediu que as legislações modernas tenham, em nome de tais ideias e princípios, abandonado a velha distinção dos efeitos entre a manumissão nos atos entre vivos e disposição de última vontade ${ }^{103}$, ficando assim "reprovada, portanto, aquella regra de Direito Romano por contraria á boa razão, e fundada em subtilezas"104. Igualmente, posiciona-se ele, contra aqueles que dizem que em tal condição o escravo não é propriamente livre e tem apenas um "direito à liberdade" (o que hoje diríamos nós, "expectativa de direito", na esteira da definição ofertada por civilistas como Ribas ou Teixeira de Freitas), reafirma Perdigão Malheiro: tal um argumento viciado pelo "terreno das ficções", que confunde as muito distintas ideias de (1) direito e (2) seu exercício; o direito de liberdade, o escravo o adquire

\footnotetext{
${ }^{99}$ MALHEIRO, Ensaio, Tomo I, p. 140, nota 379: "Prazo ou termoé o tempo ou época de que depende o direito ou obrigação, ou que o resolve ou extingue. Póde ser a quo (in diem ou ex die), isto é, aquelle desde o qual a obrigação tem sua existência; ad quem (ad diem) aquelle até o qual ella dura. O primeiro transforma-se quando incerto em condição suspensiva; o segundo tem a natureza de resolutiva. - V. Pothier, Obrig. cit.; Savigny Dir. Rom. Cit. Tomo. 3. \$\$123 a 127”. Ribas - para quem o termo é um "limite posto no tempo á eficácia de uma relação jurídica" também os denominava de termo primordial (in diem ou ex die) - que não adia a aquisição do direito, mormente seu exercício - e final (ad diem), cf. RIBAS, Curso, Tomo II, p. 402-408.

${ }^{100}$ MALHEIRO, Ensaio, Tomo I, p. 140.

${ }^{101}$ MALHEIRO, Ensaio, Tomo I, p. 141.

${ }^{102}$ MALHEIRO, Ensaio, Tomo I, p. 165.

${ }^{103}$ Cita no ponto como legislação moderna, o Código da Prússia (arts. 162, 163 e 483) e, entre os juristas modernos Lobão, Melo Freire e Coelho da Rocha.

${ }^{104}$ MALHEIRO, Ensaio, Tomo I, p. 165, nota 682.
} 
desde a manumissão, na verdade, reintegrando um estado latente natural; é seu exercício pleno e gozo que ficam retardados.

A disciplina se resolve no princípio já bastante destacado ao longo de todo o Ensaio: "em tudo quando tem de favorável ás alforrias taes disposições [condições, prazos, e também modos ${ }^{105}$ e cláusulas], são ellas aceitáveis entre nós como Direito subsidiário"106, direito este intermediado não apenas pela sistemática do direito civil, mas decantado pelo jurista ao observar a realidade social e o princípio de liberdade que advém do direito natural.

\section{A questão dos statuliberi}

O estatuto do statuliber - ou, seguindo a expressão traduzida de Teixeira de Freitas, do "estado-livre" - é um ponto técnico que se liga à matéria das alforrias condicionais fideicomissárias. É por ocasião da discussão a respeito do statuliber que a obra de Malheiro apresenta tanto a versão mais completa de seu argumento em prol da liberdade (que veremos neste tópico) quanto, já discutida, a metodologia de depuração do direito romano subsidiário através da boa razão.

Segundo Malheiro, desde o direito romano um escravo manumitido (i) sob condição suspensiva, ou (ii) com um prazo ou termo in diem ou ex die era constituído num status ou posição jurídica diferente do escravo em condições habituais; ele não era ainda um liberto, mas possuía um estatuto diverso: nem liberto nem mais um escravo, era um statuliber. Os romanos designavam por statuliberi aqueles que, para se tornarem libertos, dependiam de alguma condição ou do alcance de algum dia designado para ta ${ }^{107}$. Nos tempos em que só se podia libertar por modo solene, só era possível constituir statuliber por testamento: tal disposição foi modificada, especialmente a partir do momento em que se pôde libertar escravos por outros modos além dos solenes.

Ainda em sua reconstrução histórica, para o jurista já os jurisconsultos romanos, ao comparar os statuliberi aos serui deixavam entrever diferenças de estatuto; ao menos, é o que Malheiro depreende da expressão de Pompônio, "em quase nada diferem"108 (i.e., para Malheiro: em alguma coisa diferem). Malheiro resume em

\footnotetext{
${ }^{105} \mathrm{O}$ modo constitui apenas um ônus ao liberto, informa Malheiro, o que não impede de modo algum a aquisição de sua liberdade. Quaisquer outras cláusulas são admitidas desde que não reprovadas por leis, pelos bons costumes, pela moral e não importassem em vexame ou fossem impossíveis.

${ }^{106}$ MALHEIRO, Ensaio, Tomo I, p. 143.

${ }^{107}$ Teixeira de Freitas assim definia: "Como a alforria pôde sêr dada por fideicommisso, á prazo, ou debaixo de condição, ha um estado médio entre a escravidão e a liberdade; e os escravos que se-achão nesse estado, têm a denominaçao de — estado-livres-. Entende-se estado-livre - aquelle, que está destinado á sêr livre depois de certo tempo, ou depois do cumprimento de uma condição-L. $1^{\circ}$ pr. Dig. de statulib”, cf. TEIXEIRA DE FREITAS, Consolidação, Tomo I, p. 36 (3a. ed., nota ao art. 42).

${ }^{108}$ Pompônio, D. 40.7.29, especialmente "Statuliberi a ceteris servis nostris nihilo paene differunt". No fragmento o jurisconsulto romano explica, assim que statuliberie seruiestão na mesma condição no que toca às actiones ex delicto ou negociais.
} 
quê se assemelhavam: (1) tal qual um escravo, o statuliber poderia ser castigado e açoitado; (2) nada adquiria para si, ressalvado o pecúlio; (3) possuía as obrigações de servilidade de um escravo; (4) podia ser vendido, alienado, dado em penhor ou hipoteca; (5) estava sujeito à abandono ou vendido para satisfazer um delito; (6) estava sujeito à usucapião. E, no entanto, ao reconhecer que ele não era propriamente nem servus, nem liber, nem libertinus, os jurisconsultos romanos - ao criar o conceito de statuliber -, implicitamente até mesmo os jurisconsultos romanos, afeitos à ficções e peculiaridades, diziam que havia algo de distinto em sua condição:

Tal é sempre o imperio e força da verdade, que elles [os juristas romanos] se virão forçados a reconhecer no escravo em taes condições um direito áliberdade; direito inauferível, como se fosse já definitivamente livre: por fórma, que ninguém podia impedir a tal indivíduo o gozo da liberdade, eis que chegasse o termo ou se verificasse a condição, fosse o proprio herdeiro, ou qualquer outra pessoa que o possuísse, estivesse onerado ou não com hypotheca, ou mesmo reduzido a captiveiro inimigo, porque a condição o acompanhava sempre, e devia religiosamente cumprir-se a disposição; era até crime alienal-o occultando a condição. Chegárão mesmo a decidir que ao statuliber não era aplicável a tortura ou açoites, por já não ser propriamente escravo, contra a doutrina de Pomponio; o que foi confirmado por uma lei de Antonino Pio ou Caracalla. Ainda mais; a liberdade foi mantida em tal caso, quer o herdeiro não pudesse cumprir a condição, quer puzesse obstáculo ao implemento della, quer este se não pudesse dar por facto alheio ao liberto. $\mathrm{O}$ favor levava, na opinião de alguns Jurisconsultos, a decidir sempre pela liberdade, ainda quando parecia (como a outros), que esta não se devêra entender adquirida ${ }^{109}$.

É neste momento do tratado também que Malheiro define, como vimos supra, a alforria não como uma doação ou transferência de propriedade - "ficções" romanas -, mas, sim, atento à "verdade em sua virginal e cândida nudez", como uma renúncia dos direitos do dominus sobre o escravo, reintegrando-lhe a posse de sua liberdade natural. Não sendo possível aplicar as disposições romanas em sua integralidade, seria preciso verificar simultaneamente o tratamento moderno da questão jurídica (alteridade temporal) e pátria (alteridade da "índole do povo").

A diferença histórica no tratamento do statuliber poderia ser mapeada, no fundo, mesmo na própria experiência romana, considerando a fase tardia e cristã de Justiniano. É tal a "razão" e "verdade das coisas" que, para Perdigão Malheiro, mesmo entre os próprios juristas romanos pode-se interpretar que pela percepção de que o statuliber claramente não era mais um escravo, mas uma pessoa (ou, até, acrescenta Perdigão Malheiro indo mais longe: homem livre) mesmo que sem formalizá-lo: afinal, já pelo direito romano justinianeu ele deixa de estar sujeito aos mesmos açoites, torturas e penas típicas de escravos; passa a ter suas aquisições reconhecidas como legítimas; devia ter garantido sua liberdade ante quaisquer embaraços; deviam ser punidos aqueles que os alienavam com fraudes; podiam até estar em juízo. Entre as legislações contemporâneas, destaca o autor, mesmo o Código da Louisiana - de um Estados Unidos que, acrescenta ele, nunca foi favorável à sorte dos escravos - o statuliber é entendido como alguém capaz de fazer aquisições (possuindo curador que os administre), que os

\footnotetext{
${ }^{109}$ MALHEIRO, Ensaio, Tomo I, p. 159-160.
} 
filhos de escravas em tal condição são livres (ainda que sujeitos a servir, como a mãe, até que estas se tornem plenamente libertas) e providenciando ordem para evitar sua recondução à escravidão.

Para o jurista mineiro, a melhor técnica jurídica se aperceberá que tal qual um menor ou um interdito qualquer, o statuliber é, pessoa livre, marcada com a suspensão no exercício da sua liberdade. Já Justiniano "em sua filosofia cristã" declarara, pensa Malheiro, não ser incompatível que, por exemplo, fosse alguém livre e estivesse sujeito a usufruto de alguém; o mesmo raciocínio se aplicaria ao statuliber, ou àqueles que se obrigam a servir a alguém de forma ajustada e por tempo determinado. E isso se dá mesmo pendendo condição ou, ainda, mediante modo, mesmo quando o escravo seja alforriado diante da exigência de prestar certos serviços a outrem por certo tempo: "O liberto, eis que aceita a alforria (nem lhe é licito recusal-a), implícita e tacitamente aceita a obrigação, quando o não faça de modo expresso; se não há contracto, há quase-contracto; e a propria Lei o dá claramente a entender"110. A metodologia é similar àquela analisada quanto a manumissão por fideicomisso; como se asseverou, é entre as páginas que discutem o estatuto do statuliber que Malheiro constrói também sua definição jurídica de alforria e discorre sobre o correto uso racional do direito romano.

É diante destas razões que, ao final da seção respectiva do Ensaio, Malheiro enuncia o estatuto jurídico do statuliber no direito pátrio. O statuliber é um liberto condicional, não mais um escravo a rigor, reprovando a regra de direito romano pelo qual servus heredis est. O statuliber tem por restituída desde o momento da manumissão a sua liberdade, ficando, no entanto, retardado o seu exercício e o pleno gozo, até o prazo ou verificada à condição, à semelhança do que ocorre com os menores. Significa que retoma sua capacidade civil e pode, também como os menores, fazer aquisições para si. Por não ser mais escravo no sentido técnico, está isento do mesmo tratamento jurídico dos escravos em vários aspectos: (1) não é passível de açoites ou penas exclusivas dos escravos; (2) não pode ser aliado, vendido, hipotecado, usucapido, sendo um crime reduzir à escravidão uma pessoa livre; (3) responde pessoal e diretamente por quaisquer delitos; (4) eventual serviço ao qual o statuliber está obrigado não tem caráter servil; (5) os filhos de uma mulher statuliber será livre e ingênuo independentemente de se ter verificado, quanto à mãe, a condição ou termo da alforria condicional, na plenitude da regra da sorte do ventre; (6) por fim, dadas as peculiaridades modernas e pátrias da escravidão, quanto aos antigos "direito dos patronos" que existiam desde o direito romano, subsistiriam apenas os deveres de respeito, piedade filial e bons ofícios. Seja como for, sua situação jurídica - seu status, para utilizar precisamente o termo romano que Perdigão Malheiro escolhe manter - é, assim, idêntica a de um liberto; alguma condição ou prazo persistem, razão para que sua forma jurídica seja distinta daquela do liberto usual (ou melhor, o tipo de liberto que todo statuliber ou liberto condicional deve estar destinado a se tornar), mas não têm o condão de barrar o

\footnotetext{
${ }^{110}$ MALHEIRO, Ensaio, Tomo I, p. 170.
} 
indivíduo da posse de sua liberdade.

\section{CONCLUSÃO}

Malheiro operou no interior de um contexto político e intelectual no qual a discussão a respeito da escravidão e da abolição era fértil, candente e sensível. Interessado no desaparecimento paulatino da escravidão para sua futura substituição pelo trabalho livre e estimulação da imigração, o jurista era uma figura notória - quiçá, um especialista - a respeito do tema da escravidão em sua época. Não é à toa que parte significativa que seu tratado jurídico a respeito do tema devote tantas páginas aos temas da alforria e da condição do statuliber. Como um homem público que se posicionava de modo "moderado" - levemos a sério a linguagem de Malheiro -, não é de causar espanto a atenção dada às formas jurídicas da manumissão dos escravos pelas lentes de intelectual e jurista, atento à civilística e a Pandectística, respondendo à discussão pública do Parlamento, da Corte, do IAB e do IHGB, todos ambientes frequentados por Perdigão Malheiro.

Sensível à sua formação jurídica paulistana e às preocupações nacionais de seu tempo, empregou bom quinhão de erudição romanística para, o que poderia parecer paradoxal, identificar um substrato normativo pátrio a respeito do tema. Entre "aquelle povo" e "nosso direito", entre o "Direito Novíssimo" e cristão de Justiniano e a necessária "boa razão" coimbrã, Malheiro esboçou uma contribuição técnica e hermenêutica para o tema da alforria. Tornou central em sua obra a regra favorável à liberdade, com o status de critério hermenêutico central, avalizado pela história, pela "índole do Povo", pelo "espírito do século" e pelo que havia de mais moderno na doutrina e literatura jurídicas estrangeiras. É por meio deste critério - irremediavelmente mediado, quando não normativamente, como geralmente se dava no amplo e ainda plural quadro normativo do século XIX, pelo saber doutrinário dos juristas - que Malheiro delineia os institutos jurídicos da escravidão e da alforria, e destrinça àquelas disposições "aplicáveis entre nós". É esta mesma metodologia - que emerge especialmente no momento de discutir a natureza jurídica da alforria e da condição do statuliber - que dá azo à sua construção doutrinária a respeito da alforria voluntária e das alforrias fideicomissária, condicional e pendente prazo.

Através da análise do tratamento jurídico desses institutos na obra - efetivamente, o manual jurídico mais detalhado a respeito do tema na década de sessenta, mais enfático do que as notas de rodapé da Consolidação de Teixeira de Freitas -, buscamos demonstrar uma das formas pelos quais o discurso jurídico podia configurar o debate a respeito da alforria em um ambiente no qual a instituição da escravidão, tendencialmente em extinção, ainda precisava ser regulada à revelia de grandes diplomas normativos pátrios. Livro ao mesmo tempo científico - em sua abordagem historicista, comparativa e "racional" - e político, a técnica jurídica ao redor do instituto da manumissão no Ensaio de Perdigão Malheiro oferece umbral para o modo como 
os juristas brasileiros do século XIX categorizavam, sistematizavam e ordenavam o mundo das relações privadas através da forma e da linguagem do direito.

\title{
(ROMAN) LAW AND (GOOD) REASON: ANALYSIS OF THE LEGAL TREATMENT OF MANUMISSION IN PERDIGÃO MALHEIRO'S ESSAY THE SLAVERY IN BRAZIL
}

\begin{abstract}
The article aims to offer a contribution of legal history to the history of Brazilian slavery in the nineteenth century, demonstrating how the Law could be mobilized to create categories and forms, to operate legal institutes and to provide legal language to social phenomena such as slavery and manumission acts. The research goes through the analysis of the legal treatise Slavery in Brazil: Historical, juridical and social essay (1866) written by Agostinho Perdigão Malheiro and focuses particularly in the technical legal institute of manumission or "alforria". The article is divided into three parts. In the first section it seeks to perceive the jurist and his work within the political, intellectual and legal context regarding the slavery and Brazilian Abolitionism questions in the second half of the nineteenth century. In the second section it describes Malheiro's legal methodology, both historical and comparative, and how this methodology operates in the tension between the application of a historical form of law (Roman law as subsidiary law) and its updating reasoning through the concept of Good Reason (the "Boa Razão"). In the third section it analyses how such legal methodology (or this kind of legal reasoning) was employed in the legal and technical treatment of the manumission, especially in the discussion of its legal nature, its modalities and the legal status of statuliber in Brazilian Law. Malheiro operates through a hermeneutical argument - the norm 'most favourable to freedom' - to forge his doctrine.
\end{abstract}

Keywords: Perdigão Malheiro; Manumission; Fidei-commissary Manumission; Statuliber; Roman Law as subsidiary Law. 


\section{BIBLIOGRAFIA}

BARBOSA, Samuel Rodrigues. "Complexidade e meios textuais de difusão e seleção do direito civil brasileiro précodificação". In FONSECA, Ricardo Marcelo; SEELAENDER, Airton Lisle Cerqueira Leite. História do direito em perspectiva. Curitiba: Juruá, 2009, p. 361-373.

BUSTAMANTE, Thomas da Rosa. "A ‘Lei da Boa Razão’ e a cultura jurídica oitocentista: prolegômeno para uma proposta de compreensão da cultura jurídica brasileira contemporânea à luz do pensamento de António Manuel Hespanha”. In Revista Estudos Filosóficos, n. 14, 2015, p. 92-1 16.

CHALHOUB, Sidney. Visões da liberdade: uma história das últimas décadas da escravidão na Corte. São Paulo: Cia das Letras, 1990.

COSTA, Pietro. Iurisdictio: semantica del potere politico nella repubblica medievale (1100-1433). Milano: A. Giuffrè Editore, 2002.

FREIRE, Paschoal José de Melo. Institutionum juris civilis lusitani: cum publici, tum privati, jussu acad. Reg. Scientiarum in lucem editus. 3a ed. Olisipone: Typographia Realis Academiae, 1797, 3 vol.

FREIRE, Pascoal de Melo. "Instituições de direito civil português: tanto público como particular". Trad. Miguel Pinto de Meneses. In: Antologia de textos sobre finanças e economia. Lisboa: Ministério das Finanças, 1966.

GILENO, Carlos Henrique. Perdigão Malheiro e as crises do sistema escravocrata do Império. 2003. 133 f. Tese (Doutorado em Sociologia) - Instituto de Filosofia e Ciências Humanas, Universidade Estadual de Campinas, São Paulo, 2003.

GUIMARÃES, Manoel Luis Salgado. "Nação e Civilização nos trópicos: o instituto histórico e geográfico brasileiro e o projeto de uma história nacional”. In: Estudos Históricos. Rio de Janeiro, n. 1, 1988, pp. 5-27.

HESPANHA, António Manuel. "Um poder um pouco mais que simbólico: juristas e legisladores em luta pelo poder de dizer o direito". In FONSECA, Ricardo Marcelo; SEELAENDER, Airton Lisle Cerqueira Leite. História do direito em perspectiva. Curitiba: Juruá, 2009, p. 149-199. 
HESPANHA, António Manuel. "Razões de decidir na doutrina portuguesa e brasileira do século XIX: um ensaio de análise de conteúdo". In Quaderni Fiorentini per la storia del pensiero giuridico moderno. Milano: Giuffrè, 2010, Vol. 39, p. 109-150.

LOUREIRO, Lourenço Trigo de. Instituições de direito civil brasileiro. Prefácio de Paulo Távora. Ed. fac-sim [4a ed. 1871]. Brasília: Senado Federal, 2004, 2 vol.

MALHEIRO, Agostinho Marques Perdigão. Indice chronologico dos factos mais notáveis da historia do Brasil desde seu descobrimento em 1500 até 1849: seguido de um succinto esboço do estado do Paiz ao findar o anno de 1849. Rio de Janeiro: Typografia de Francisco Paula Brito, 1850.

MALHEIRO, Agostinho Marques Perdigão. A Escravidão no Brasil: Ensaio histórico, jurídico e social: $1^{\text {a }}$ parte (jurídica), Direito sobre os escravos e libertos. Rio de Janeiro: Typografia Nacional, 1866, vol. 1-3.

MALHEIRO, Agostinho Marques Perdigão. A Escravidão no Brasil: Ensaio histórico, jurídico e social: 2a parte (Índios). Rio de Janeiro: Typografia Nacional, 1867, vol. 2-3.

MALHEIRO, Agostinho Marques Perdigão. A Escravidão no Brasil: Ensaio histórico, jurídico e social: $3^{\text {a }}$ parte (Africanos). Rio de Janeiro: Typografia Nacional, 1867, vol. 3-3.

MALHEIRO, Agostinho Marques Perdigão. Ilegitimidade da propriedade constituída sobre o escravo. Natureza de tal propriedade. Justiça e conveniência da abolição da escravidão, e em que termos. Rio de Janeiro, 7 de setembro de 1863.

MALHEIRO, Agostinho Marques Perdigão. Discurso proferido na sessão da Câmara Temporária de 12 de julho de 1871 sobre a proposta do governo para reforma do estado servil. Rio de Janeiro: Typografia Imp. e Const. de J. Villeneuve \& C., 1871.

NABUCO, Joaquim. A Escravidão (1870): compilado por José Antônio Gonsalves de Mello, apresentação e organização Leonardo Dantas Silva, prefácio Manuel Correia de Andrade. Recife: FUNDAJ-Editora Massangana, 1988. 
NABUCO, Joaquim. O Abolicionismo. Londres: Typographia de Abraham Kingdon, 1883.

NABUCO, Joaquim. Escravos! Versos Francezes a Epicteto. Rio de Janeiro: Typographia de G. Leuzinger \& Filhos, 1886.

PENNA, Eduardo Spiller. Pajens da Casa Imperial: jurisconsultos, escravidão e a Lei de 1871. Campinas: Ed. UNICAMP, 2001.

PORTUGAL. Ordenações Filipinas: decima-quarta edição segundo a primeira de 1603 e a nona de Coimbra de 1824, addicionada com diversas notas philologicas, historicas e exegeticas, em que se indicão as diferenças entre aquellas edições e a vicentina de 1747 ... desde 1603 ate o prezente, por Candido Mendes de Almeida. Rio de Janeiro: Typographia do Instituto Philomathico, 1870, 5 v.

RIBAS, Antônio Joaquim. Curso de Direito Civil Brasileiro. Prefácio de Antônio de Pádua Ribeiro. Ed. fac-sim [2a ed. 1880]. Brasília: Senado Federal, 2003, 2 vol.

SANTANA, Rogério Barreto. Perdigão Malheiro e a comparação histórica na crise da escravidão no Brasil, 18631871. 2014. 162 f. Dissertação (Mestrado em História Social) - Faculdade de Filosofia e Ciências Humanas, Universidade São Paulo, São Paulo, 2014.

SILVA JÚNIOR, Waldomiro Lourenço. Entre a escrita e a prática: direito e escravidão no Brasil e em Cuba, c. 1760-1871. 2015. 341 f. Tese (Doutorado em História Social) - Faculdade de Filosofia e Ciências Humanas, Universidade São Paulo, São Paulo, 2015.

SOARES, Caetano Alberto. Memoria para melhorar a sorte dos nossos escravos: lida na sessão geral do Instituto dos Advogados Brasileiros no dia 7 de setembro de 1845 pelo Dr. Caetano Soares Alberto. Rio de Janeiro: Typhografia Imparcial de Francisco de Paula Brito, 1847.

TEIXEIRA DE FREITAS, Augusto. Consolidação das Leis Civis. Prefácio de Ruy Rosado de Aguiar. Ed. fac-sim [3a ed., 1876]. Brasília: Senado Federal, 2003, 2 vol.

TELLES, José Homem Corrêa. Comentário critico a lei da Boa Razão em data de 18 de agosto de 1769. [1ª ed.: 
1824]. Lisboa: Typographia de Maria de Madre Reis de Deus, 1865.

VENÂNCIO FILHO, Alberto. Das arcadas ao bacharelismo: 150 anos de ensino jurídico no Brasil. São Paulo: Perspectiva, 2004.

WEHLING, Arno. "O escravo ante a lei civil e a lei penal no Império (1822-1871)". In WOLKMER, Antônio Carlos (org.). Fundamentos de História do Direito. 4a ed. Belo Horizonte: Del Rey, 2009, p. 387-407.

WIEACKER, Franz. História do Direito Privado Moderno. 4a ed. Trad. António Manuel Hespanha. Lisboa: Fundação Calouste Gulbenkian, 2010.

Trabalho enviado em 27 de março de 2018

Aceito em 12 de janeiro de 2019 